\title{
Article \\ Zinc Oxide and Silver Nanoparticle Effects on Intestinal Bacteria
}

\author{
Ami Yoo, Mengshi Lin and Azlin Mustapha *D \\ Food Science Program, Division of Food Systems and Bioengineering, University of Missouri, \\ Columbia, MO 65211, USA; yooami1218@hotmail.com (A.Y.); LinMe@missouri.edu (M.L.) \\ * Correspondence: mustaphaa@missouri.edu; Tel.: +1-(573)-882-2649
}

check for updates

Citation: Yoo, A.; Lin, M.; Mustapha,

A. Zinc Oxide and Silver

Nanoparticle Effects on Intestinal Bacteria. Materials 2021, 14, 2489.

https://doi.org/10.3390/ma14102489

Academic Editors: Paweł

Piotr Pomastowski and

Viorica Railean-Plugaru

Received: 20 March 2021

Accepted: 7 May 2021

Published: 12 May 2021

Publisher's Note: MDPI stays neutral with regard to jurisdictional claims in published maps and institutional affiliations.

Copyright: (c) 2021 by the authors. Licensee MDPI, Basel, Switzerland. This article is an open access article distributed under the terms and conditions of the Creative Commons Attribution (CC BY) license (https:// creativecommons.org/licenses/by/ $4.0 /)$.

\begin{abstract}
The application of nanoparticles (NPs) for food safety is increasingly being explored. Zinc oxide $(\mathrm{ZnO})$ and silver (Ag) NPs are inorganic chemicals with antimicrobial and bioactive characteristics and have been widely used in the food industry. However, not much is known about the behavior of these NPs upon ingestion and whether they inhibit natural gut microflora. The objective of this study was to investigate the effects of $\mathrm{ZnO}$ and Ag NPs on the intestinal bacteria, namely Escherichia coli, Lactobacillus acidophilus, and Bifidobacterium animalis. Cells were inoculated into tryptic soy broth or Lactobacilli MRS broth containing 1\% of NP-free solution, 0, 12, 16, $20 \mathrm{mM}$ of ZnO $\mathrm{NPs}$ or $0,1.8,2.7,4.6 \mathrm{mM} \mathrm{Ag} \mathrm{NPs}$, and incubated at $37^{\circ} \mathrm{C}$ for $24 \mathrm{~h}$. The presence and characterization of the NPs on bacterial cells were investigated by scanning electron microscopy (SEM), transmission electron microscopy (TEM), and energy-dispersive X-ray spectroscopy (EDS). Membrane leakage and cell viability were assessed using a UV-visible spectrophotometer and confocal electron microscope, respectively. Numbers of treated cells were within $1 \log \mathrm{CFU} / \mathrm{mL}$ less than those of the controls for up to $12 \mathrm{~h}$ of incubation. Cellular morphological changes were observed, but many cells remained in normal shapes. Only a small amount of internal cellular contents was leaked due to the NP treatments, and more live than dead cells were observed after exposure to the NPs. Based on these results, we conclude that $\mathrm{ZnO}$ and $\mathrm{Ag}$ NPs have mild inhibitory effects on intestinal bacteria.
\end{abstract}

Keywords: antimicrobials; intestinal bacteria; zinc oxide nanoparticles; silver nanoparticles

\section{Introduction}

Nanotechnology is widely applied in many industrial fields, such as information and communication technology, biotechnology, pharmaceuticals, computer electronics, medicinal technology, and the food industry [1-4]. Recently, nanoparticles made of carbon, metal, and metal oxide, have been applied in various areas due to their unique characteristics [2].

Engineered nanoparticles (NPs) are materials that have applications in the food industry, such as in food packaging, to improve the shelf life of food and to prevent microbial contamination [5,6]. Among the metal-based NPs, ZnO NP is one of the most well-studied. $\mathrm{ZnO}$ NPs are unique in that they are not only stable under high temperatures and pressures that are typically employed in food processing conditions, but they are also generally regarded as safe (GRAS) [7,8]. The antimicrobial activity of $\mathrm{ZnO}$ toward bacteria is dependent on many factors, including the size of the NP, the concentration used, and the type of bacteria targeted (Gram-positive or Gram-negative) [9,10]. Silver (Ag) NPs are inorganic antibacterial agents used in the pharmaceutical and medical industries and have a significant potential for a wide range of biological applications, including as antifungal and antibacterial agents for antibiotic resistant organisms and for preventing infections [11]. Like ZnO NPs, the size and concentration of Ag NPs also directly affect their antimicrobial properties [12,13]. However, the exact mechanisms of effect of $\mathrm{ZnO}$ and $\mathrm{Ag}$ NPs on bacteria are still unclear.

To improve the properties and reduce the production costs of NPs, many synthetic methods for generating NPs have been developed [14,15]. More recently, the green synthe- 
sis method offers a novel and potential alternative to chemically-synthesized NPs [16-18]. Our own previous work [19] demonstrated that green-synthesized Ag NPs using turmeric extract showed antimicrobial effect against pathogenic bacteria. Although recent studies have demonstrated the antimicrobial activities of $\mathrm{ZnO}$ and Ag NPs toward foodborne pathogenic and spoilage microorganisms [9,11,20-29], not much is known about the behavior of $\mathrm{ZnO}$ and $\mathrm{Ag}$ NPs upon ingestion and whether they inhibit natural gut microflora, which are a major part of the human defense system.

In this study, we investigated the effect of $\mathrm{ZnO}$ and Ag NPs on three important intestinal bacteria, i.e., Escherichia coli, Lactobacillus acidophilus, and Bifidobacterium animalis. The modes of action of $\mathrm{ZnO}$ and Ag NPs on the growth of the bacterial cells were also studied by a combination of microscopic and analytical methods. The results of this study demonstrated that the cytotoxic effects exhibited by $\mathrm{ZnO}$ and $\mathrm{Ag} \mathrm{NPs}$, at the concentrations and sizes tested, against these intestinal bacteria were minimal.

\section{Materials and Methods}

\subsection{Preparation of Intestinal Bacterial Strains}

E. coli K-12, L. acidophilus $\mathrm{ADH}$, and B. animalis Bif- 6 were from the culture collection of the Food Microbiology Laboratory at the University of Missouri, Columbia, MO. E. coli K-12 was grown in tryptic soy broth supplemented with $0.5 \%$ yeast extract (TSBY; Difco Labs., BD Diagnostics Systems, Sparks, MD, USA). L. acidophilus ADH and B. animalis Bif-6 were grown in Lactobacilli MRS broth (Difco Labs.) supplemented with $0.05 \%$ cysteine. All three strains were freshly prepared in $10 \mathrm{~mL}$ of the respective broth medium and tubes were incubated aerobically for E. coli and anaerobically for the other two strains for 18-20 h at $37^{\circ} \mathrm{C}$ (final cell concentrations of $\sim 10^{9} \mathrm{CFU} / \mathrm{mL}$ ) [30].

\subsection{Preparation of Zinc Oxide and Silver Nanoparticles}

$\mathrm{ZnO} N \mathrm{NP}$ suspensions with an average particle size of $77 \mathrm{~nm}$ were purchased from Alfa Aesar (Ward Hill, MA, USA). The concentration of the original suspension was $12 \mathrm{M}$. Ag NPs were synthesized by a chemical reduction method according to Ratyakshi and Chauhan (2009) [31]. The size of the ZnO NPs and Ag NPs was determined by analyzing transmission electron microscopy (TEM) images using the ImageJ software available at https:/ /imagej.softonic.kr/download (accessed on 3 April 2021). One hundred different measurements were taken of the $\mathrm{ZnO}$ data and 130 different measurements were taken of the Ag NP data [30].

\subsection{Effect of $\mathrm{ZnO}$ and $\mathrm{Ag} N$ Ns on the Growth of Bacterial Cells}

Freshly (overnight) grown cultures of E. coli K-12, L. acidophilus ADH and B. animalis Bif- 6 were inoculated into the respective broth medium (TSBY or MRS) containing 0, 12, $16,20 \mathrm{mM}$ of $\mathrm{ZnO} \mathrm{NP}, 0,1.8,2.7,4.6 \mathrm{mM}$ of Ag NP, or $1 \%$ of NP-free solutions. The NP-free solutions were prepared by filtering the respective NP suspensions through an inorganic anodisc membrane with a $20 \mathrm{~nm}$ pore size (Whatman Inc., Clifton, NJ, USA). NP suspensions and the NP-free solution were added to the broth media before autoclaving.

Tubes containing E. coli K-12 were incubated in a shaker incubator set at $37^{\circ} \mathrm{C}$. Tubes inoculated with L. acidophilus ADH and B. animalis Bif-6 were first placed in an anaerobic jar with GasPak gas generators (GasPak EZ Anaerobe Container System, BD Diagnostics) before incubating in a shaker incubator set at medium shaking at $37^{\circ} \mathrm{C}$. The reason for the shaking incubation was to avoid aggregation of the NPs in the broth and to allow for a consistent contact between the bacterial cells and the NPs. The samples were diluted with peptone water and plated at varying times for up to $24 \mathrm{~h}$ in the respective agar media, viz. Tryptic Soy Agar supplemented with yeast extract for E. coli K-12, and Lactobacilli MRS agar supplemented with cysteine for L. acidophilus ADH and B. animails Bif- 6 . The sampling times between 0 and $12 \mathrm{~h}$ differed for experiments with $\mathrm{ZnO}$ and those with Ag NPs. In order to capture the most accurate changes in cell numbers, these respective sampling time points were selected based on a preliminary experiment that indicated changes in cell 
numbers after $\mathrm{ZnO}$ exposure occurred after $6 \mathrm{~h}$ and those after Ag NP exposure occurred before $6 \mathrm{~h}[30]$.

\subsection{Morphological Examination of the Bacterial Cells}

Scanning electron microscopy (SEM) was used to examine the morphological changes of the bacterial cells before and after treating with ZnO NPs and Ag NPs. The three bacterial strains treated or untreated with NPs were fixed with a primary fixative (2.5 glutaraldehyde, $2 \%$ paraformaldehyde in $0.1 \mathrm{M} \mathrm{Na}$-cacodylate buffer, $\mathrm{pH} 7.4$ ). The samples were then rinsed three times with ultrapure water, followed by dehydration with a series of ethanol solutions $(10 \%, 30 \%, 50 \%, 70 \%, 90 \%$, and $100 \%)$. The dehydrated samples were immediately dried by a critical point dryer (Auto-Samdri 815 Automatic Critical Point Dryer; Tousimis, Rockville, MD, USA), mounted on SEM stubs and coated with a thin layer of carbon using a sputter coater (K575X Turbo Sputter Coater; Emitech, Ltd., Kent, UK). The coated samples were observed under SEM (FEI Quanta 600, FEI Company, Hillsboro, OR, USA) [30].

Energy dispersive spectroscopy (EDS) coupled with SEM was used for elemental analysis and was effective in locating and identifying NPs that were attached to the cells. Untreated cells and NPs attached to treated cells were spotted to analyze the elements. Three spots were selected in each sample to analyze the elements (Figures 4e, 5e, 6e, 7e, 8e and 9e).

Transmission electron microscopy (TEM) was employed to characterize the size of the NPs and to observe the morphology of the bacterial cells following treatment with $\mathrm{ZnO}$ and Ag NPs. Three samples of bacterial cells treated with and without NPs were fixed with a primary fixative and microwaved under vacuum conditions in a Pelco Biowave (Ted Pella, Inc., Redding, CA, USA) at $120 \mathrm{~W}$. The samples were rinsed with $0.1 \mathrm{M}$ cacodylate buffer and embedded in histogel, followed by a secondary microwave fixation with a buffered ( $0.1 \mathrm{M}$ cacodylate, $0.01 \mathrm{M}$ of 2-mercaptoethanol, and $0.13 \mathrm{M}$ of sucrose) $1 \%$ osmium tetroxide. The samples were then quickly rinsed three times with $0.1 \mathrm{M}$ 2-mercaptoethanol and $0.13 \mathrm{M}$ of sucrose and then rinsed three times with ultrapure water. Then, samples were dehydrated with ethanol solutions $(20,50,70,90$, and $100 \%)$ and $100 \%$ acetone solution. The samples were infiltrated with Spurr's resin and polymerized at $60{ }^{\circ} \mathrm{C}$ for $24 \mathrm{~h}$. The sample blocks were processed in $85 \mathrm{~nm}$ thin sections with Leica Ultracut UCT ultramicrotomes (Leica Microsystems $\mathrm{GmbH}$, Wetzlar, Germany). The sections were placed on 200 mesh thin bar grids and post-stained for $20 \mathrm{~min}$ with $5 \%$ uranyl acetate and $10 \mathrm{~min}$ with Sato's triple lead stain. Stained samples were then observed in a JEOL 1400 (JEOL, Ltd., Tokyo, Japan) transmission electron microscope [30].

\subsection{Determination of Membrane Leakage}

Overnight cultures of the three strains were inoculated into the respective broth medium containing $0,12,16,20 \mathrm{mM}$ of $\mathrm{ZnO} N P s$ and allowed to sit for $10 \mathrm{~h}$ at $37^{\circ} \mathrm{C}$. Similarly, strains were exposed to $0,1.8,2.7,4.6 \mathrm{mM}$ of $\mathrm{Ag}$ NPs for $6 \mathrm{~h}$ at $37^{\circ} \mathrm{C}$. After incubation, $1 \mathrm{~mL}$ of the treated bacterial suspensions was centrifuged at $18,200 \times g$ for $5 \mathrm{~min}$ and resuspended in sterile peptone water. The light absorbance of the suspensions was examined using a UV-visible spectrophotometer (UV-1650 PC, Suzhou Instruments Manufacturing Co. Ltd., Suzhou, China) at a wavelength of $260 \mathrm{~nm}$ (for DNA absorbance) and $280 \mathrm{~nm}$ (for protein absorbance). All experiments were replicated twice [30].

\subsection{Assessment of the Viability of Bacterial Cells}

To determine the viability of the treated cells, $1 \mathrm{~mL}$ of samples was centrifuged at $18,200 \times g$ for $5 \mathrm{~min}$. Cell pellets were washed with $1 \mathrm{~mL}$ of $0.85 \% \mathrm{NaCl}$ and stained using the Bac Light ${ }^{\mathrm{TM}}$ Bacterial Viability Kit (Invitrogen, Carlsbad, CA, USA) according to the manufacturer's instructions. The samples were incubated at room temperature in the dark for $15 \mathrm{~min}$ and $8 \mu \mathrm{L}$ of the stained bacterial suspension were placed between a glass slide 
and a $170 \mu \mathrm{m}$ thick coverslip. Samples were observed under a Zeiss LSM 510 META (Zeiss LSM 510 META NLO, Carl Zeiss Ltd., Jena, Germany) confocal microscope [30].

\subsection{Statistical Data Analysis}

The SAS GLM procedure (SAS 9.2, Copyright 2002-2007; SAS Institute Inc., Cary, $\mathrm{NC}$, USA) was used to evaluate the effects of $\mathrm{ZnO}$ and Ag NPs on growth and membrane leakage of bacterial strains. Tukey's test was applied to determine differences between different concentrations of NP treatments at a significance level of 0.05 .

\section{Results}

\subsection{Characterization of $\mathrm{ZnO}$ and $\mathrm{Ag} N \mathrm{NP}$}

Most of the $\mathrm{ZnO}$ NPs were either round or rectangular-shaped with an average size of $77.9 \mathrm{~nm}$ (Figure 1a). The size distribution histogram of the ZnO NPs indicated that the majority of the NPs were in the range of $60-80 \mathrm{~nm}$ in diameter (Figure 1b). According to Zhang et al. (2007), ZnO NPs may be present in the form of agglomerates due to synthetic processing. Hence, ultrasonication and dispersants, such as polyethylene glycol (PEG), polyvinylpyrolidone (PVP) and bovine serum albumin (BSA) are often used to disintegrate NP agglomerates [21]. However, the ZnO NPs used in this study were relatively well-dispersed with only slight agglomeration in ultra-purified water without the use of sonification or dispersants (Figure 1a). Also, incubating the cells with shaking allowed for the avoidance of $\mathrm{ZnO} N P$ aggregation in the broth.

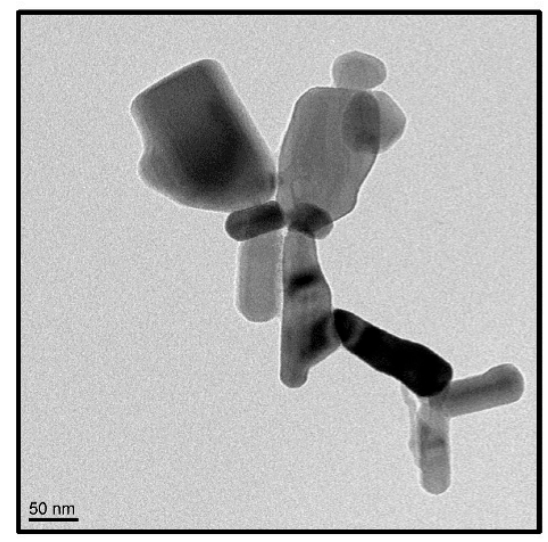

a

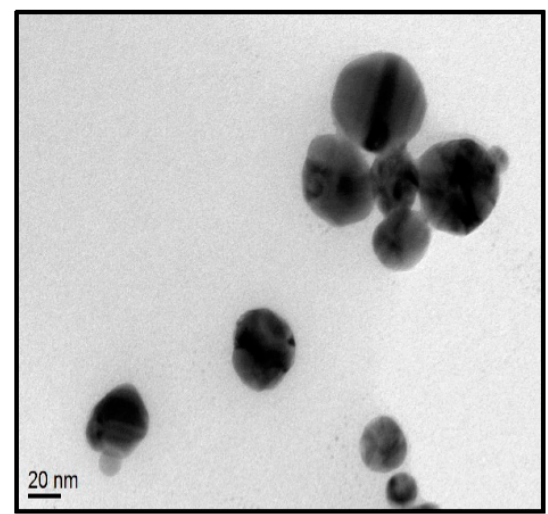

C

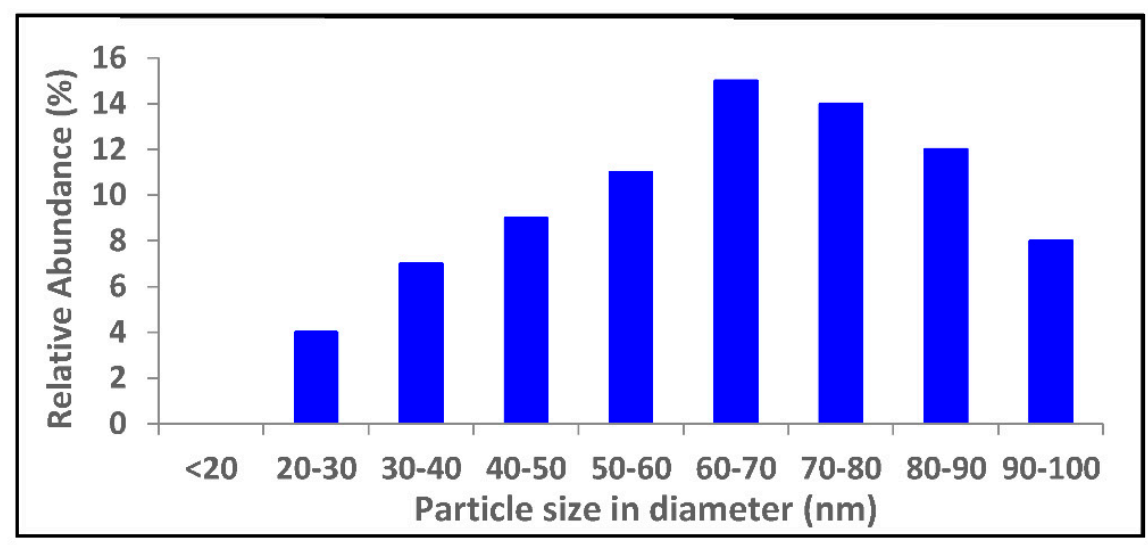

b

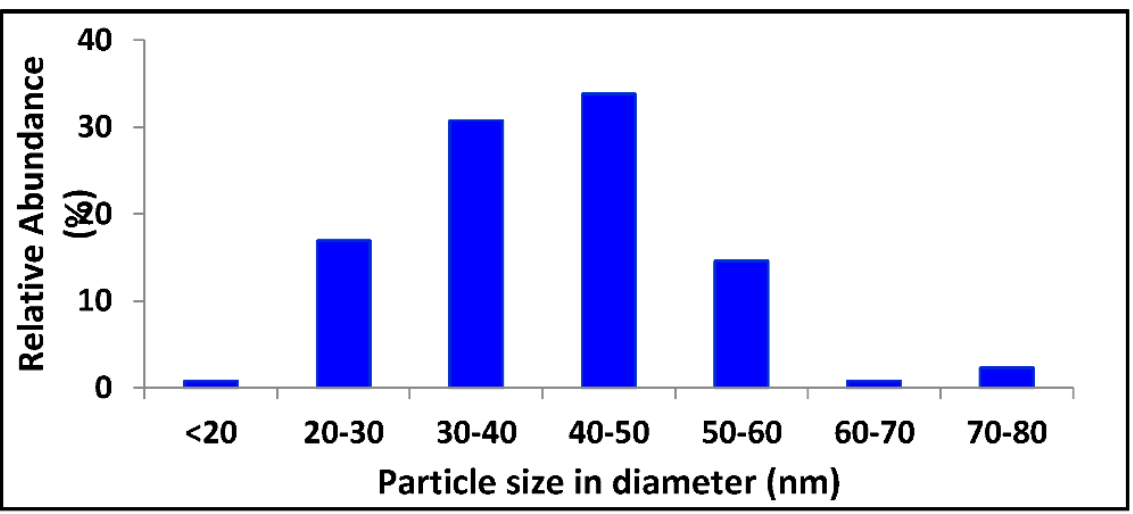

d

Figure 1. TEM image and size distribution of ZnO NPs (a,b) and TEM image and size distribution of Ag NPs (c,d). 
The shape of Ag NPs observed under TEM was uniformly spherical and they were well-dispersed (Figure 1c). The majority of the Ag NPs measured fell in the range of $30-50 \mathrm{~nm}$ in diameter with an average size of $40.2 \mathrm{~nm}$ (Figure 1d) [30].

\subsection{Effect of $\mathrm{ZnO} N$ Ps on Bacterial Growth}

As shown in Figure 2, the growth of E. coli for the control and all treated samples, including the NP-free sample, exhibited very similar patterns. Even at the highest concentration $(20 \mathrm{mM})$ of $\mathrm{ZnO} N P s$, no significant effects on $E$. coli $(p \leq 0.05)$ were observed (Figure 2a). For L. acidophilus, the numbers of treated cells were within $1 \log \mathrm{CFU} / \mathrm{mL}$ less than those of the control for up to $12 \mathrm{~h}$ of incubation. After $12 \mathrm{~h}$, the cell numbers of treated samples increased slowly, and by the end of $24 \mathrm{~h}$, their numbers showed no significant differences $(p \leq 0.05)$ as compared to the control (Figure $2 b)$. Numbers of B. animalis in treated samples were less than $1 \log \mathrm{CFU} / \mathrm{mL}$ lower than the control for up to $7 \mathrm{~h}$ of incubation. After $8 \mathrm{~h}$, the number of treated cells followed similar patterns as the control and NP-free sample, and by the end of $24 \mathrm{~h}$, the numbers of treated cells were within $1 \log \mathrm{CFU} / \mathrm{mL}$ that of the control (Figure 2c). L. acidophilus was reduced by $11.4 \%$ after $10 \mathrm{~h}$ of exposure to $\mathrm{ZnO}$ NPs, which was the highest reduction percentage as compared to the other exposure times. About a $10 \%$ reduction of $B$. animalis numbers was observed between 6 and $7 \mathrm{~h}$ of exposure to $\mathrm{ZnO}$ NPs, after which, less than $5 \%$ of reduction was observed. However, at the end of $24 \mathrm{~h}$, a more than $10 \%$ reduction in the number of $B$. animalis cells was observed (Figure 2c) [30].

\subsection{Effect of $A g$ NPs on the Bacterial Growth}

Ag NPs at 1.8, 2.7 and $4.6 \mathrm{mM}$ had a significant inhibitory effect $(p \leq 0.05)$ on E. coli for up to $9 \mathrm{~h}$ (Figure 3a). Increasing concentrations of Ag NPs from 1.8 to $4.6 \mathrm{mM}$ more greatly inhibited the growth of $E$. coli for up to $10 \mathrm{~h}$, but no differences in numbers were seen as compared to the controls after $10 \mathrm{~h}$. Compared to E. coli, L. acidophilus and B. animalis were less inhibited by Ag NPs (Figure 2b,c). The growth patterns of treated L. acidophilus and $B$. animalis were similar to those of their controls and NP-free controls. Concentrations of Ag NPs of up to $1.8 \mathrm{mM}$ showed no significant effects on L. acidophilus and B. animalis. Ag NPs at 2.7 and $4.6 \mathrm{mM}$ showed a significant effect $(p \leq 0.05)$ on L. acidophilus and B. animalis for up to $9 \mathrm{~h}$. No significant effects of Ag NPs after $12 \mathrm{~h}$ of exposure were observed for L. acidophilus and B. animalis. After $9 \mathrm{~h}$ of exposure to Ag NPs, a less than $5 \%$ of cell reduction was observed [30].

\subsection{Morphological Examination of Bacterial Cells Treated with $\mathrm{ZnO}$ and $\mathrm{Ag}$ NPs}

No significant changes in bacterial morphology (size, shape, appearance) were observed after $\mathrm{ZnO} N P$ treatments for $10 \mathrm{~h}$ (Figure 4). Some $\mathrm{ZnO}$ NPs were observed to adhere to E. coli cells (arrows, Figure $4 \mathrm{~b}$ ). The sizes of $\mathrm{ZnO}$ NPs attached to the bacterial cells appeared larger and clustered as compared to those demonstrated in the corresponding TEM image (Figure 4a). This may be due to agglomeration of $\mathrm{ZnO}$ NPs during the incubation period. TEM images allowed for direct visualization of intracellular morphological changes of bacterial cells before and after treatment with ZnO NPs. The bacterial cells were normal in size with intact intracellular structures and well-maintained intracellular contents (Figure 4c). Some deformations of bacterial cells were observed after treatment with $\mathrm{ZnO}$ NPs (Figure 4d). These include a distortion of the cell wall and cell membrane with overall cell shrinkage and a less dense appearance of the cytoplasm that may indicate membrane disruption and leakage of cell content when cells were treated with the higher concentration $(20 \mathrm{mM})$ of $\mathrm{ZnO}$ NPs. However, not all cells were damaged, which supports the result of the growth studies where no effect of ZnO NPs on E. coli was demonstrated (Figure 2a) [30]. 

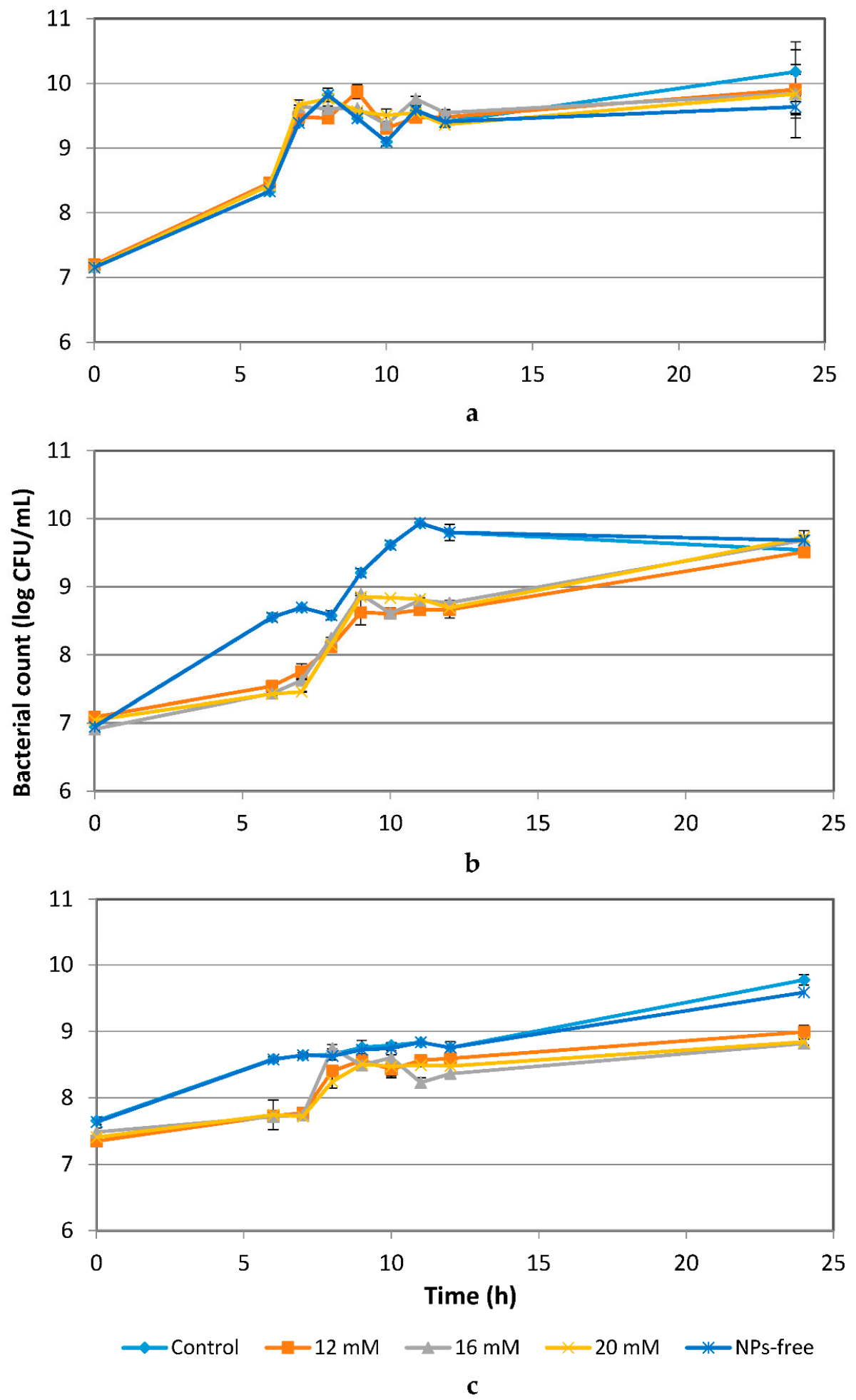

Figure 2. Effects of ZnO NPs on the growth of E. coli (a), L. acidophilus (b) and B. animals (c) over a 24-h period. 

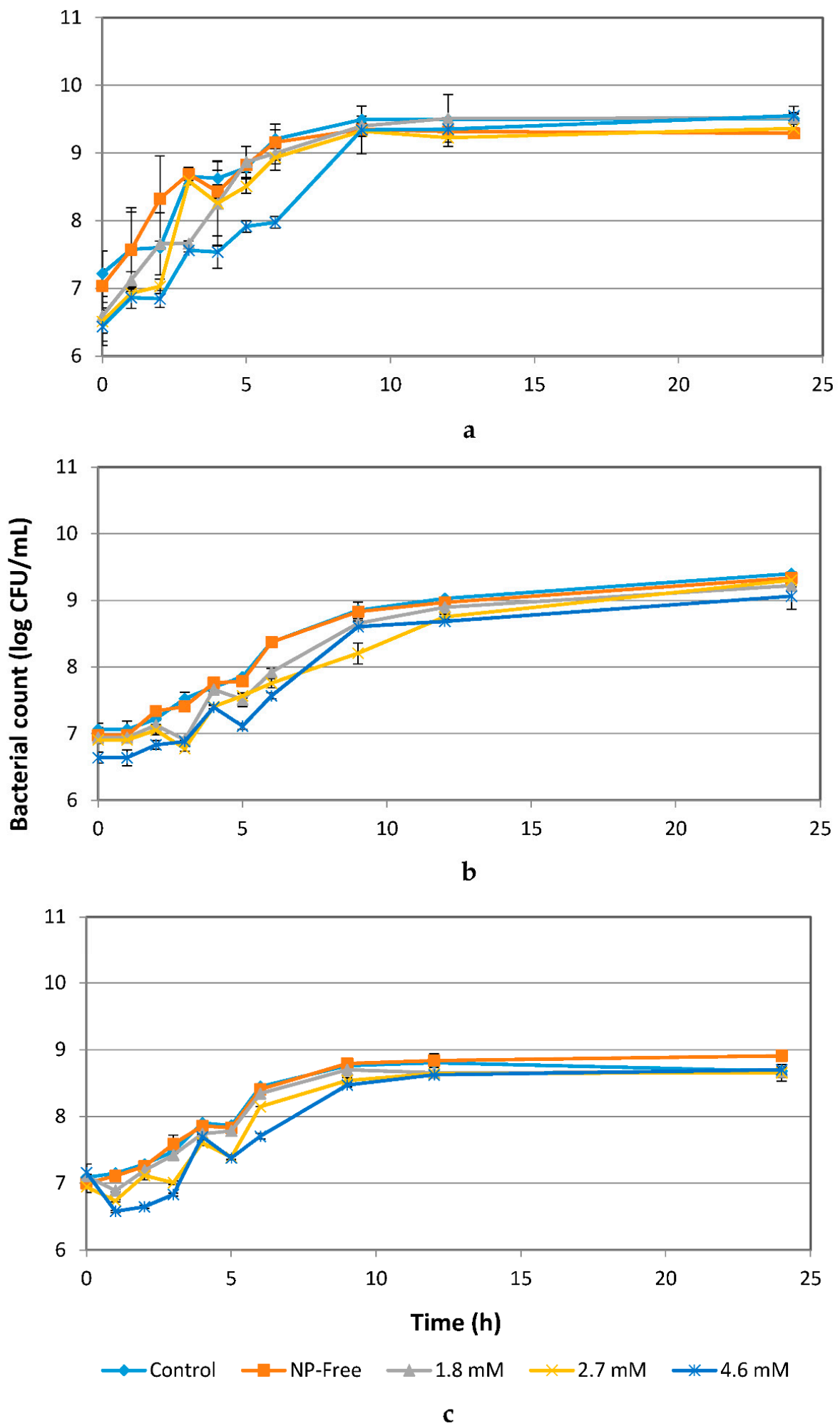

Figure 3. Effects of Ag NPs on the growth of E. coli (a), L. acidophilus (b) and B. animals (c) over a 24-h period. 


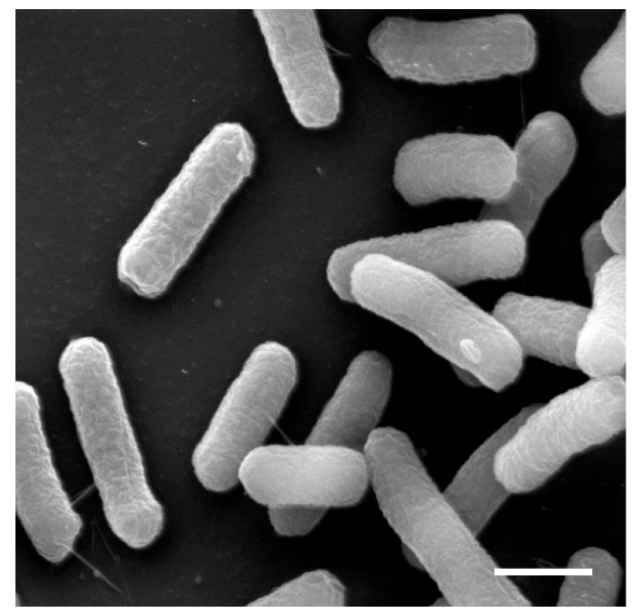

a

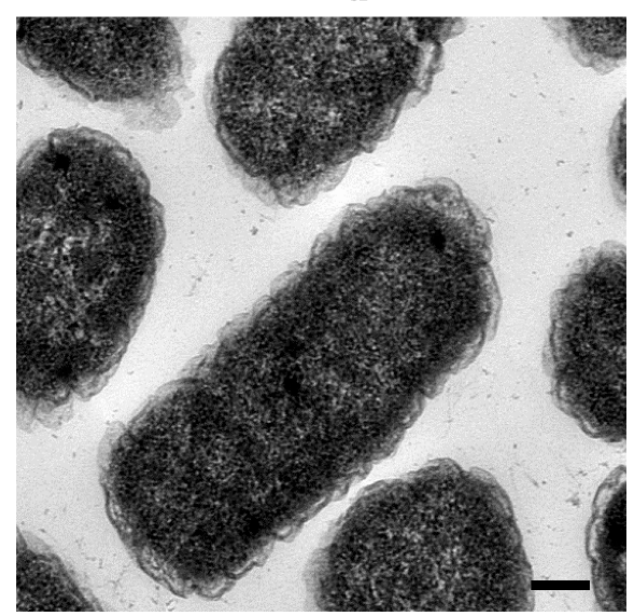

C

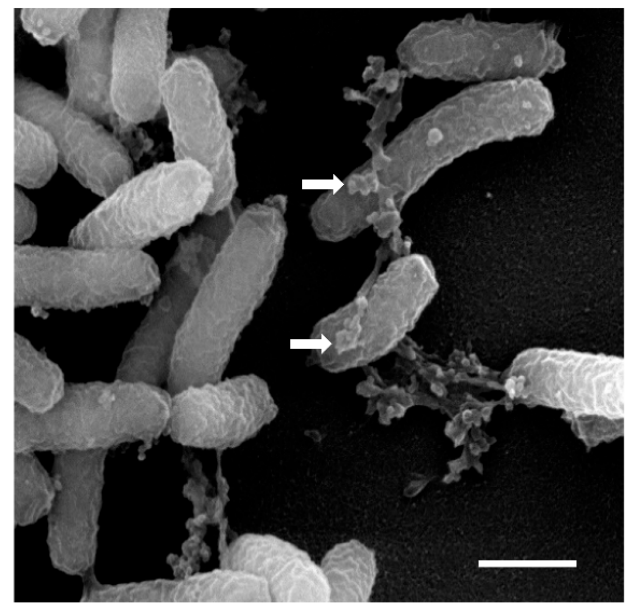

b

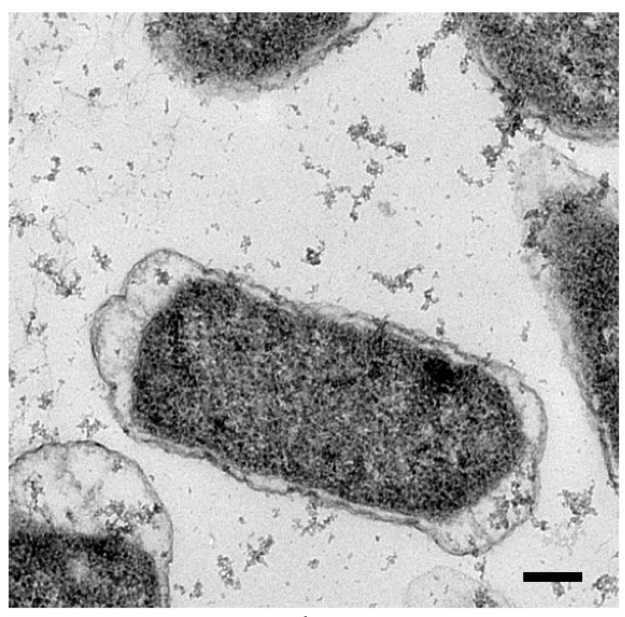

d
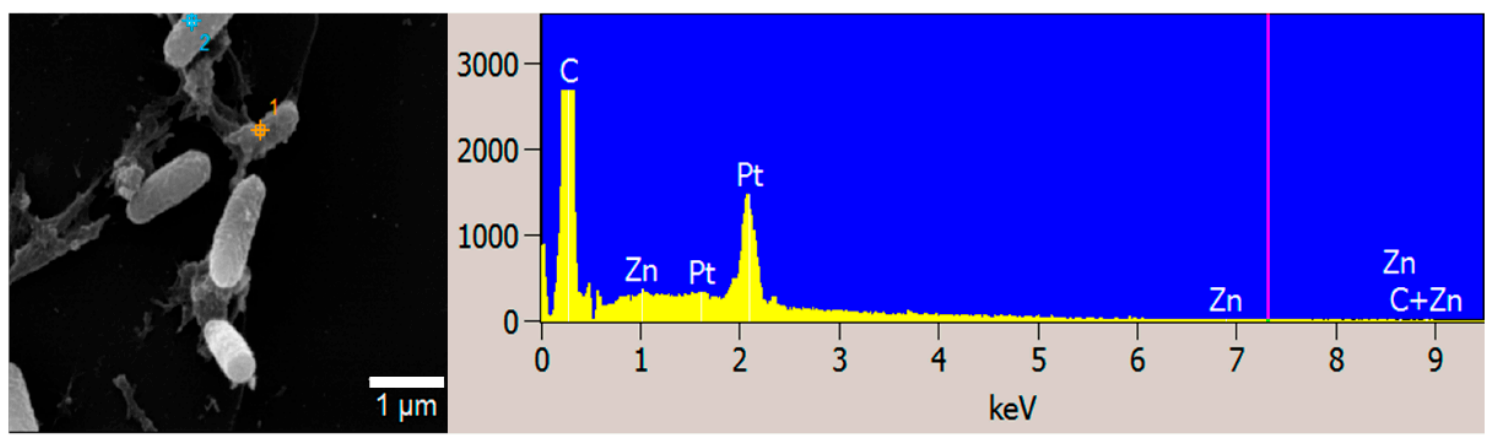

e

Figure 4. SEM (a,b) and TEM (c,d) images of E. coli untreated with ZnO NPs (a,c) and treated with $20 \mathrm{mM}$ ZnO NPs $(\mathbf{b}, \mathbf{d})$. White arrows indicated clusters of ZnO NPs. SEM-EDS analysis shows ZnO presence on cell surfaces (e). SEM scale bar $(\mathbf{a}, \mathbf{b})=1 \mu \mathrm{m}$, TEM scale bar $(\mathbf{c}, \mathbf{d})=0.2 \mu \mathrm{m}$.

Obvious changes in the cell morphology of L. acidophilus were observed after treatment with ZnO NPs, whereby ZnO NPs adhered to the cells (arrows, Figure 5b), and deformed them into a spiral and twisted shape. Many spiral or twisted shaped cells were found in the sample treated with ZnO NPs and TEM images show deformed cell membrane and intracellular morphological changes with cell leakage occurring in treated L. acidophilus (Figure 5d), as opposed to undamaged cells with a normal rod shape in the control group (Figure 5a,c). B. animalis showed similar morphological changes as L. acidophilus (Figure 6). 
Many deformed cells and spiral-shaped cells were observed in the treated samples. Further, damaged cells in the treated samples showed leakage of cell contents (Figure 6d) [30].

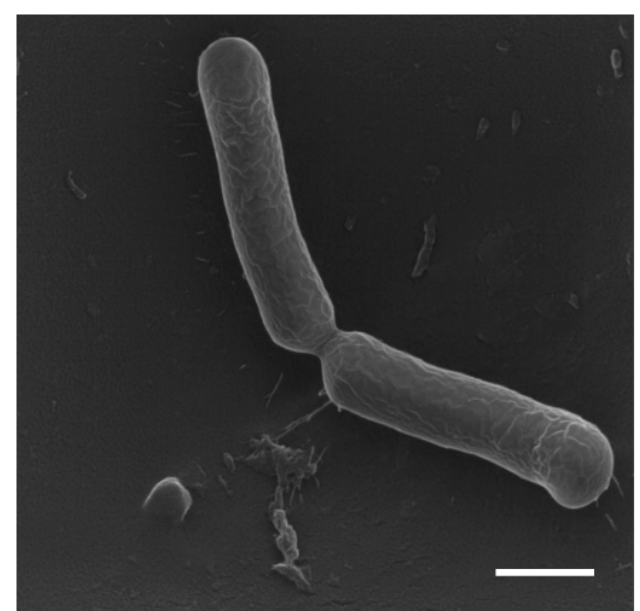

a

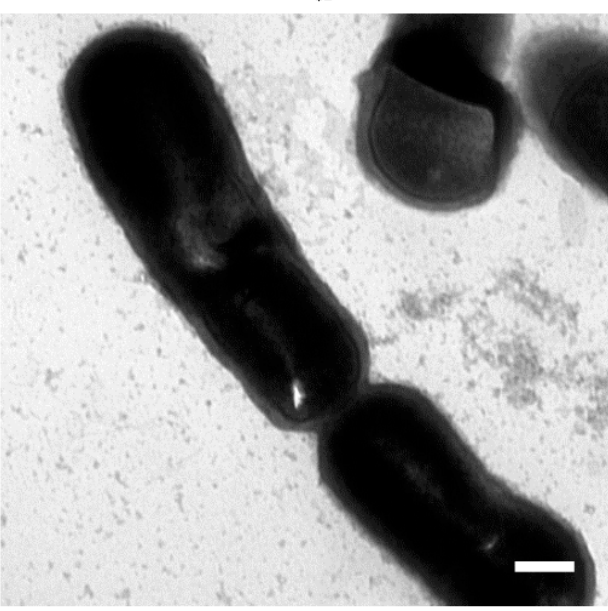

c

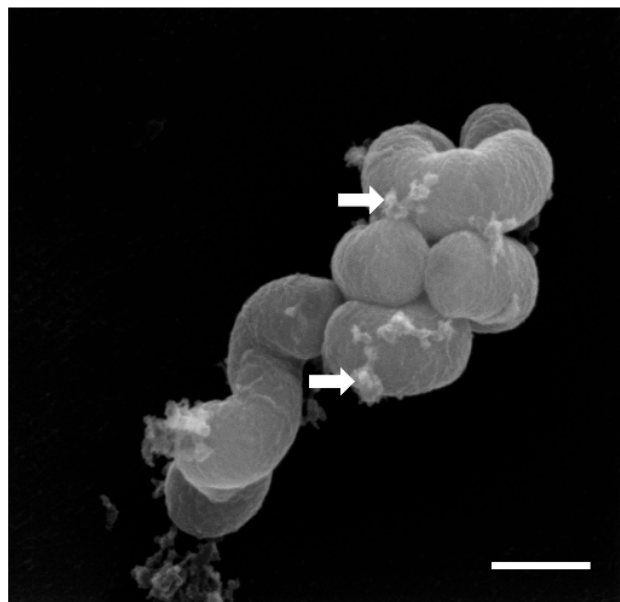

b

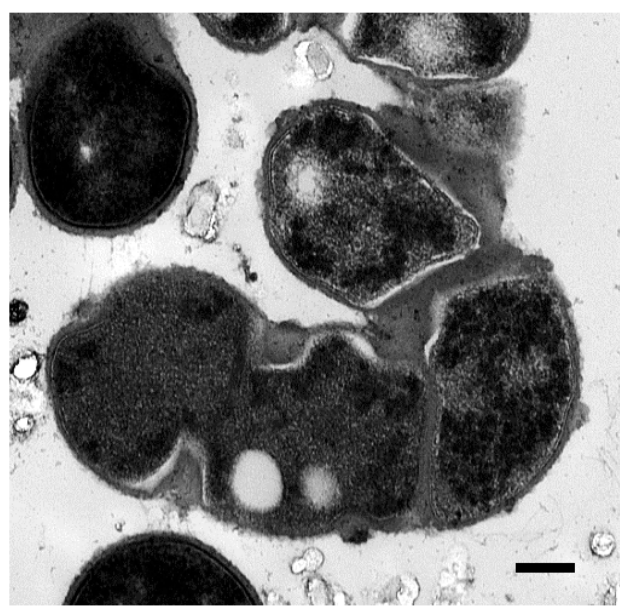

d
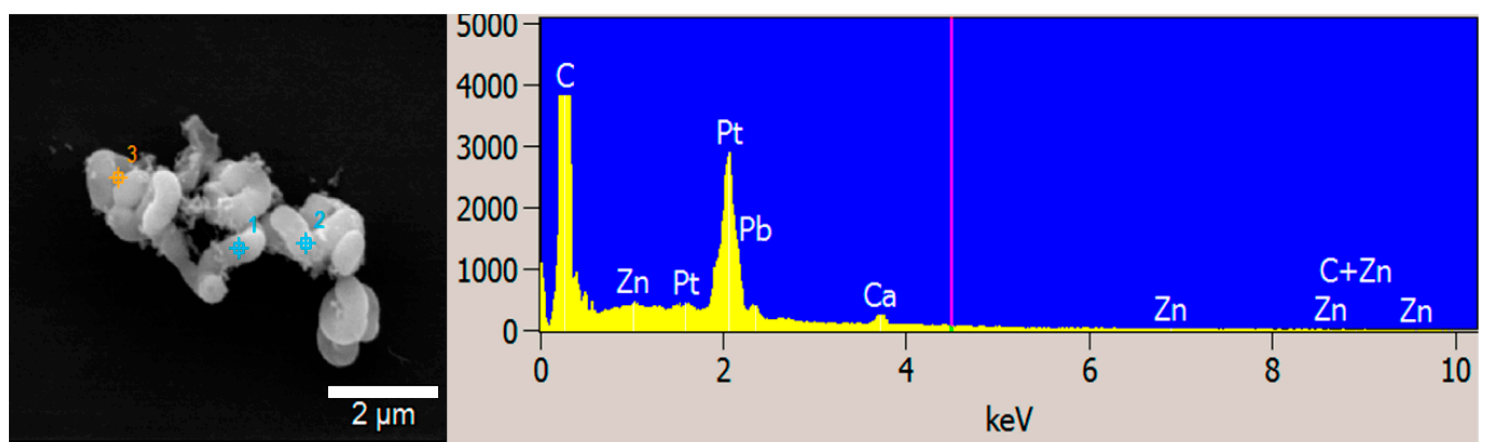

e

Figure 5. SEM (a,b) and TEM (c,d) images of L. acidophilus untreated with ZnO NPs (a,c) and treated with $20 \mathrm{mM}$ ZnO NPs $(\mathbf{b}, \mathbf{d})$. SEM-EDS analysis shows ZnO presence on cell surfaces (e). White arrows indicated clusters of ZnO NPs. SEM scale $\operatorname{bar}(\mathbf{a}, \mathbf{b})=1 \mu \mathrm{m}$, TEM scale bar $(\mathbf{c}, \mathbf{d})=0.2 \mu \mathrm{m}$. 


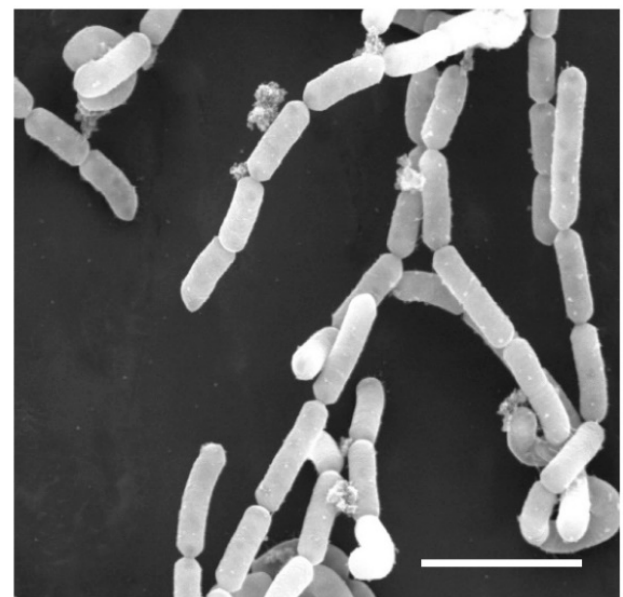

a

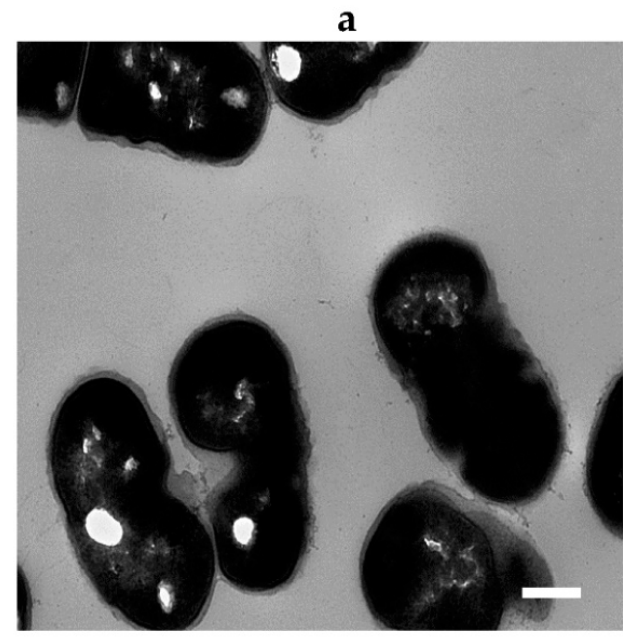

c

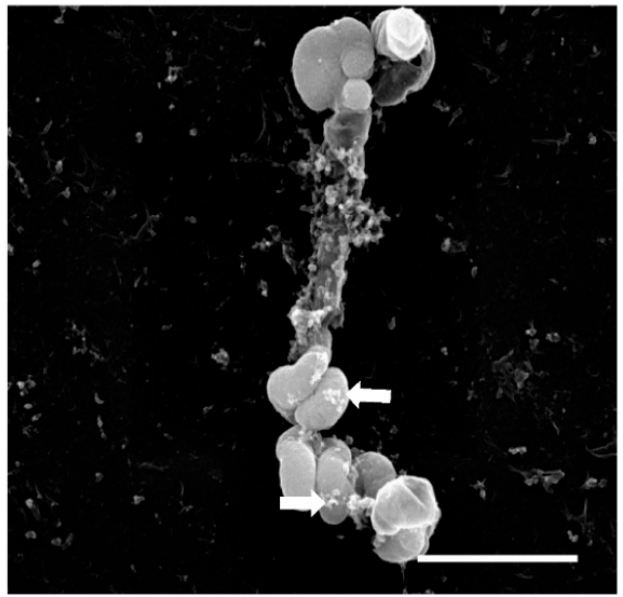

b

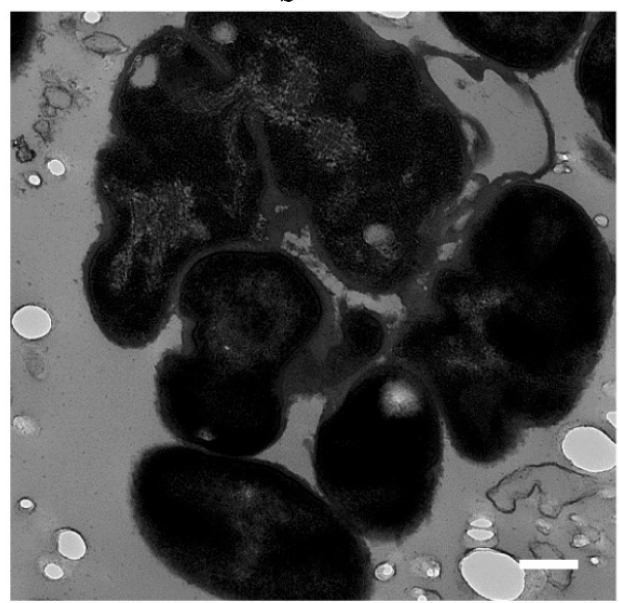

d
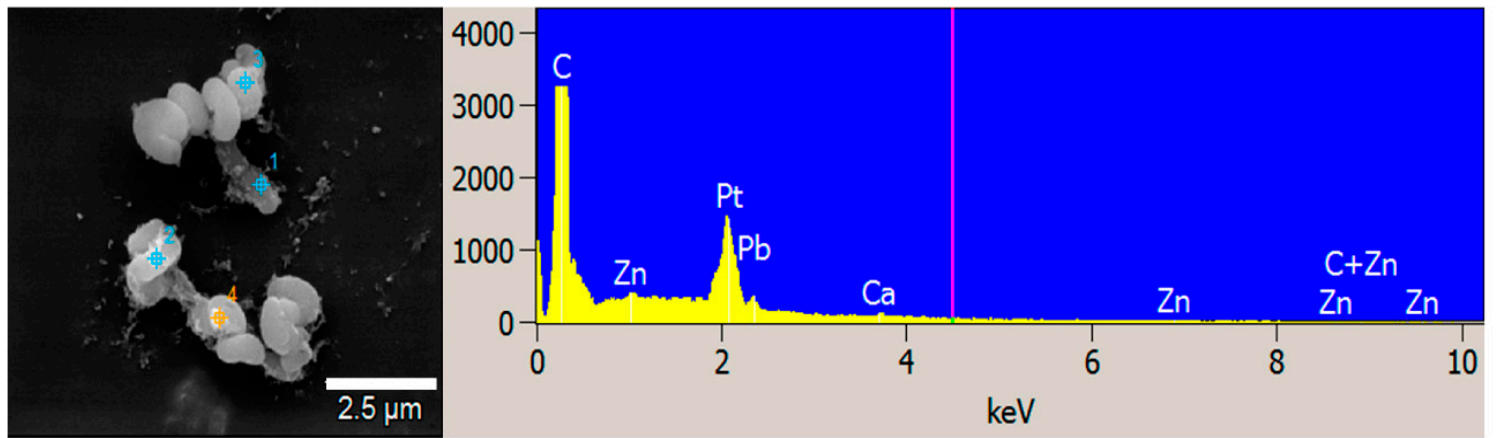

e

Figure 6. SEM (a,b) and TEM (c,d) images of B. animalis untreated with ZnO NPs $(\mathbf{a}, \mathbf{c})$ and treated with $20 \mathrm{mM} Z \mathrm{ZnO}$ NPs $(\mathbf{b}, \mathbf{d})$. SEM-EDS analysis shows ZnO presence on cell surfaces (e). White arrows indicated clusters of ZnO NPs. SEM scale $\operatorname{bar}(\mathbf{a}, \mathbf{b})=3 \mu \mathrm{m}$, TEM scale bar $(\mathbf{c}, \mathbf{d})=0.2 \mu \mathrm{m}$.

No significant changes in the external appearance of $E$. coli cells were observed after treatment with Ag NPs for $6 \mathrm{~h}$ (Figure 7). Ag NPs were seen attached to the bacterial cells (arrows, Figure $7 \mathrm{~b}$ ) in clusters instead of singly. Similar agglomeration was observed for $\mathrm{ZnO} \mathrm{NP}$-treated cells (Figures $4 \mathrm{~b}$ and $5 \mathrm{~b}$ ). Untreated cells were normal in size with intact intracellular structures and well-organized intracellular contents (Figure 7a,c). However, deformation of the cell membrane and an almost emptied cytoplasmic content was observed after treatment with $4.6 \mathrm{mM} \mathrm{Ag} \mathrm{NPs} \mathrm{(Figure} \mathrm{7d).} \mathrm{The} \mathrm{bacterial} \mathrm{cells} \mathrm{were} \mathrm{sur-}$ 
rounded by Ag NPs and null cells found in samples treated with Ag NPs, indicating that intracellular contents had leaked due to damage to the cell membrane [30].

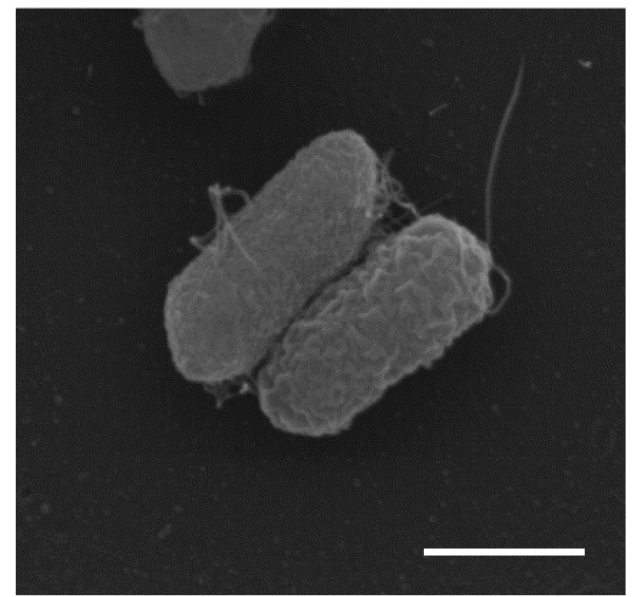

$\mathbf{a}$

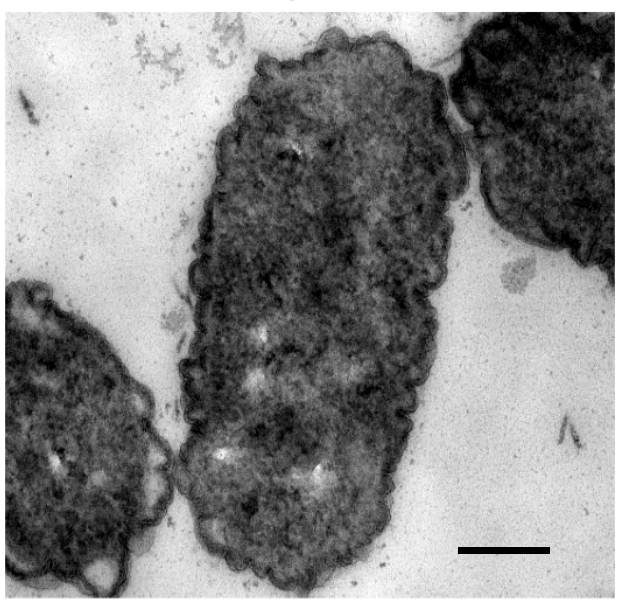

c

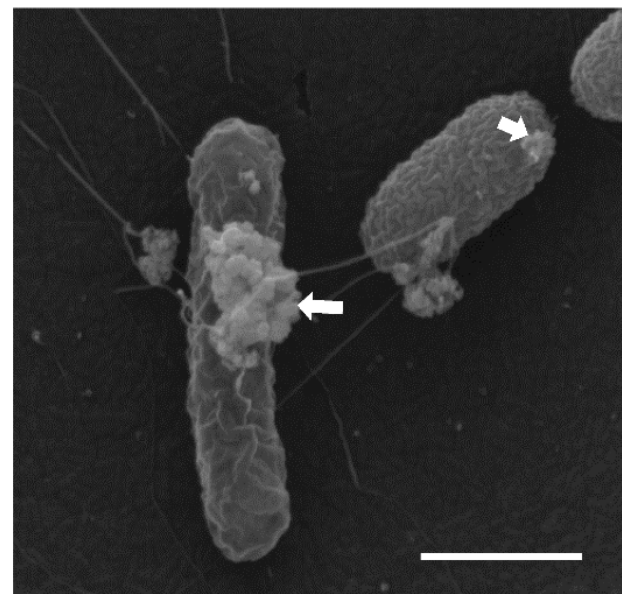

b

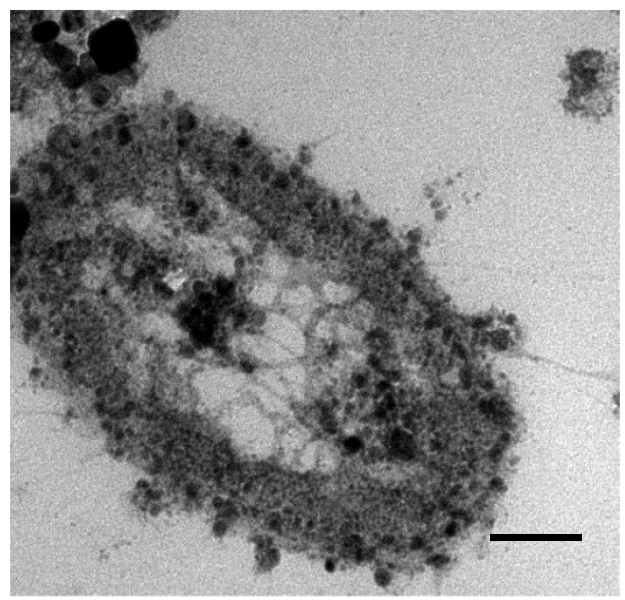

d
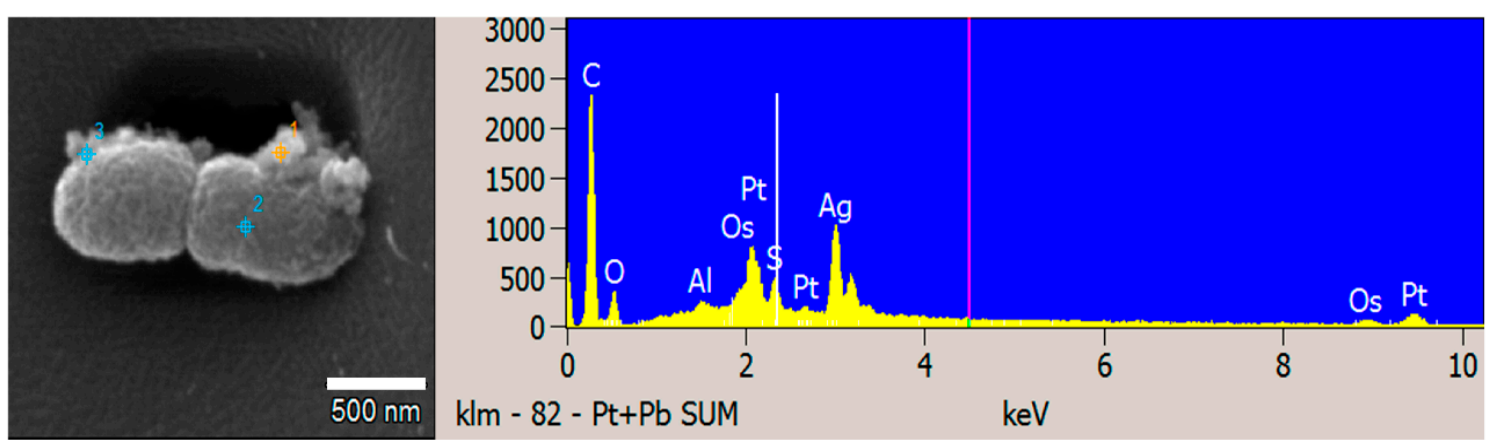

e

Figure 7. SEM (a,b) and TEM (c,d) images of E. coli untreated with Ag NPs (a,c) and treated with 4.6 mM Ag NPs (b,d). SEM-EDS analysis shows Ag NP presence on cell surfaces (e). White arrows indicated clusters of Ag NPs. SEM scale bar $(\mathbf{a}, \mathbf{b})=1 \mu \mathrm{m}$, TEM scale bar $(\mathbf{c}, \mathbf{d})=0.2 \mu \mathrm{m}$.

No significant changes in bacterial morphology were observed before and after treatment with Ag NPs for L. acidophilus cells when observed under SEM (Figure 8a,b). However, TEM images of L. acidophilus showed some differences, such as distortion of cell membranes and leakage of internal contents of treated cells (Figure 8d). As seen in the SEM image (Figure $8 \mathbf{b}$ ), not all cells were damaged, and there were still many cells in normal size and 
shapes. This is supported by the plate count number of about $10^{7} \mathrm{CFU} / \mathrm{mL}$ (Figure $3 \mathrm{~b}$ ), which is only $1 \log \mathrm{CFU} / \mathrm{mL}$ less than the control. Similar results were observed with B. animalis (Figure 9) [30].

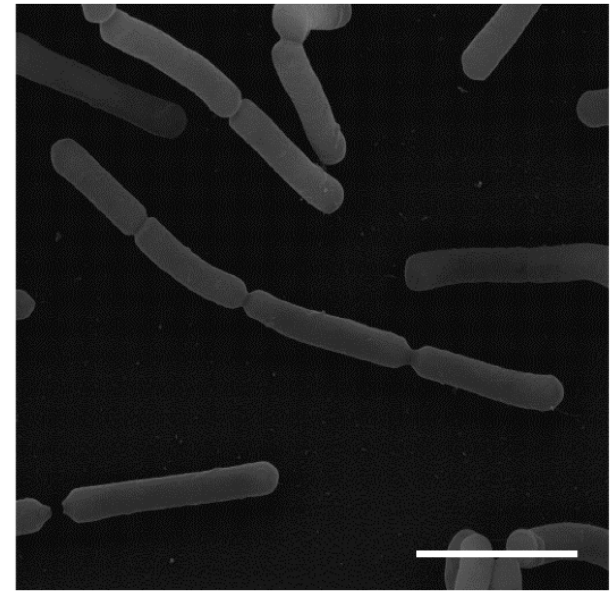

a

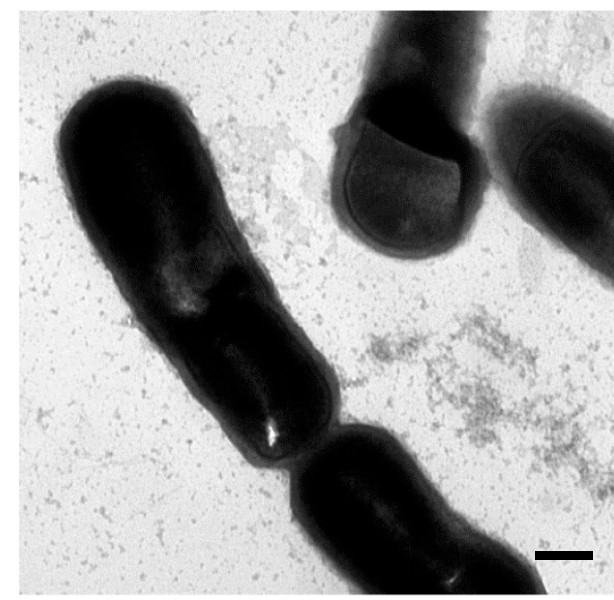

C

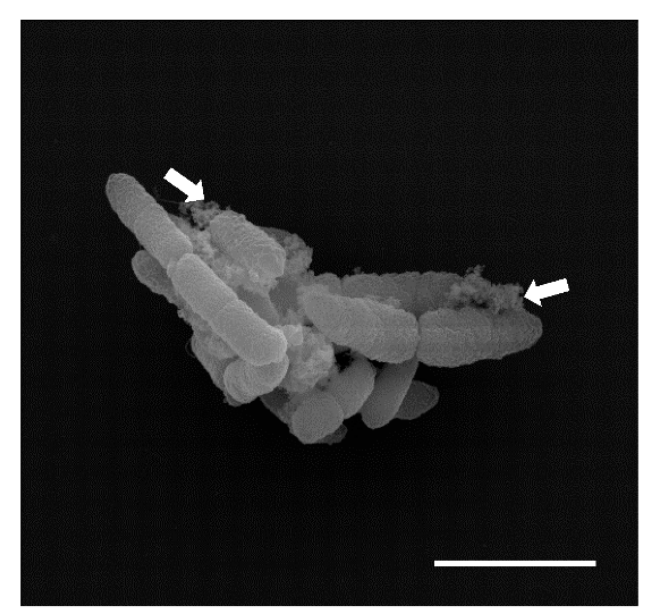

b

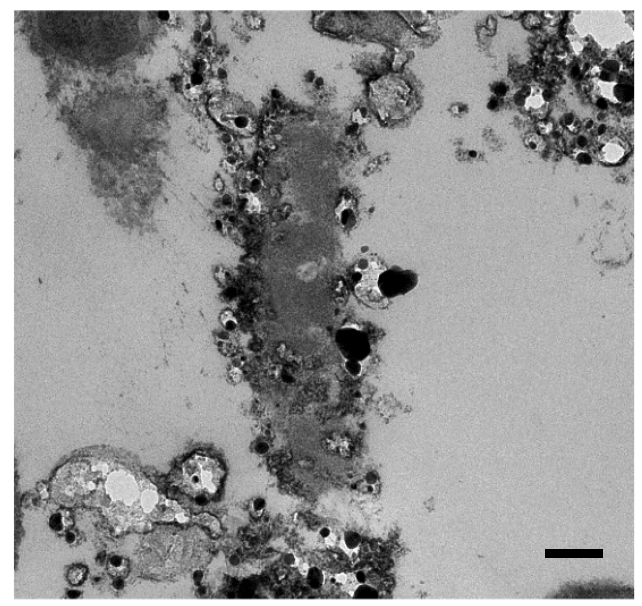

d
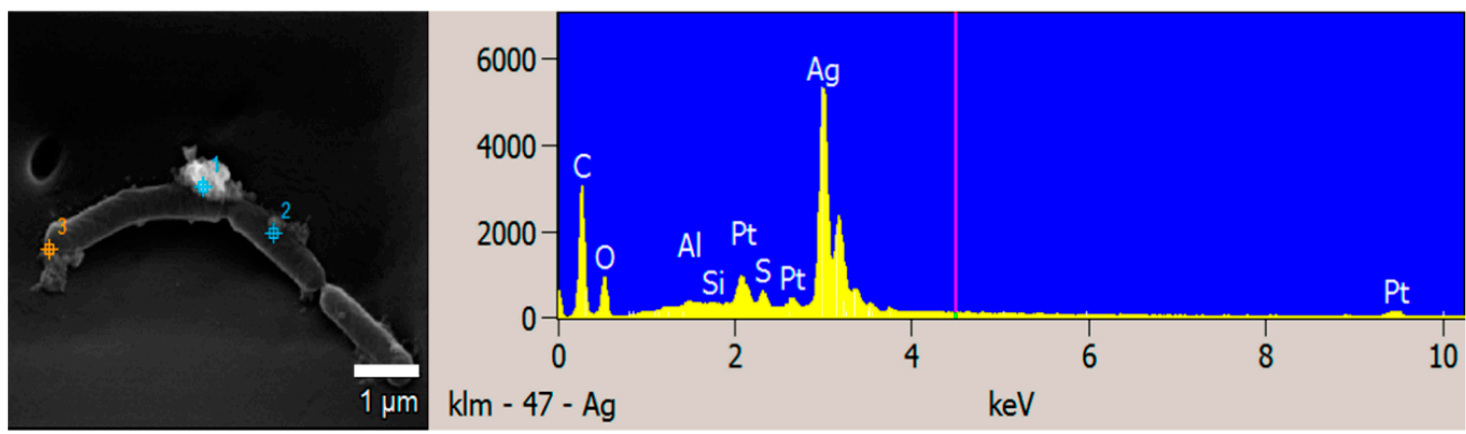

e

Figure 8. SEM $(\mathbf{a}, \mathbf{b})$ and TEM $(\mathbf{c}, \mathbf{d})$ images of L. acidophilus untreated with Ag NPs $(\mathbf{a}, \mathbf{c})$ and treated with $4.6 \mathrm{mM}$ Ag NPs $(\mathbf{b}, \mathbf{d})$. SEM-EDS analysis shows Ag NP presence on cell surfaces (e). White arrows indicated clusters of Ag NPs. SEM scale $\operatorname{bar}(\mathbf{a}, \mathbf{b})=3 \mu \mathrm{m}$, TEM scale bar $(\mathbf{c}, \mathbf{d})=0.2 \mu \mathrm{m}$. 


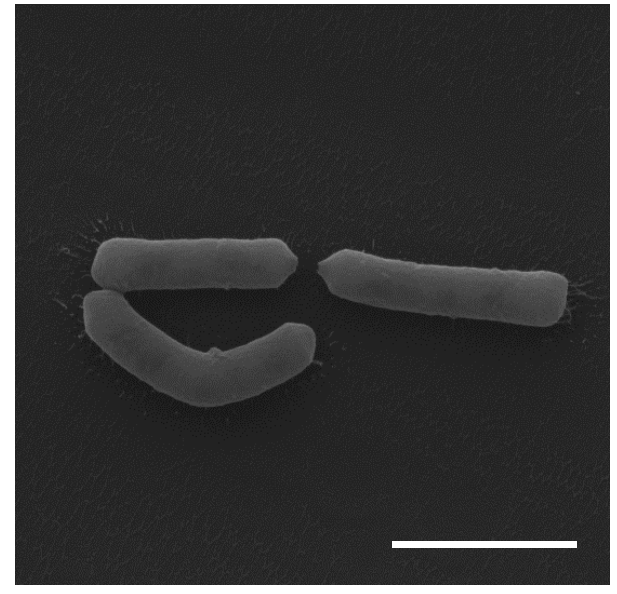

a

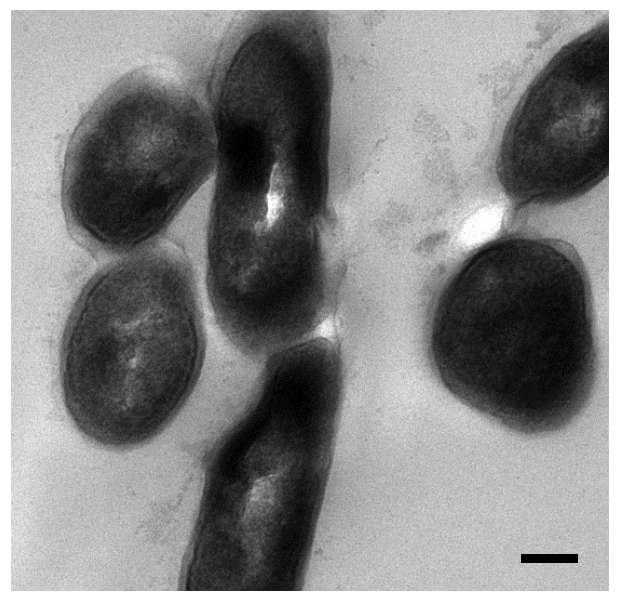

C

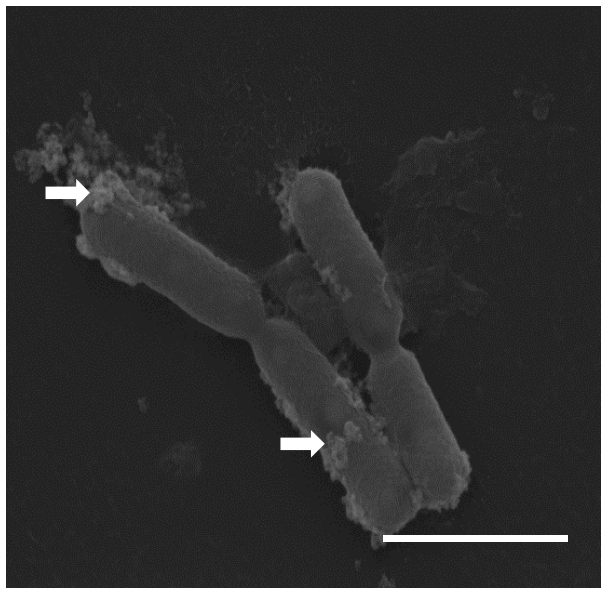

b

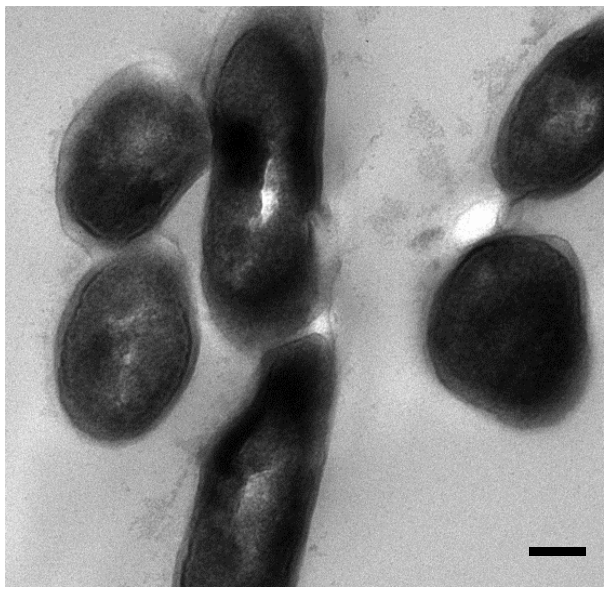

d
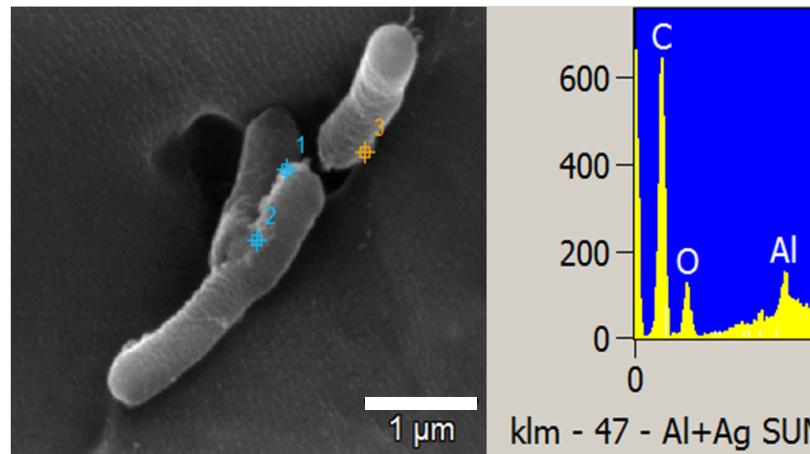

$\mathrm{klm}-47-\mathrm{Al}+\mathrm{Ag}$ SUM

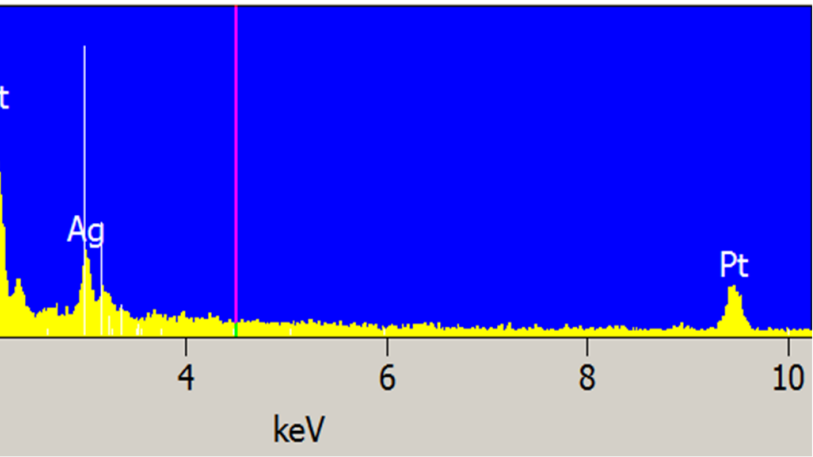

$\mathbf{e}$

Figure 9. SEM $(\mathbf{a}, \mathbf{b})$ and TEM $(\mathbf{c}, \mathbf{d})$ images of B. animalis untreated with Ag NPs $(\mathbf{a}, \mathbf{c})$ and treated with $4.6 \mathrm{mM}$ Ag NPs $(\mathbf{b}, \mathbf{d})$. SEM-EDS analysis shows Ag NP presence on cell surfaces (e). White arrows indicate clusters of Ag NPs. SEM scale bar $=2 \mu \mathrm{m}$, TEM scale bar $=0.2 \mu \mathrm{m}$.

EDS is a common technique for analysis of the elemental composition of a specimen. It is also capable of generating a map of multiple chemical elements of interest at specifically pointed spots. SEM-EDS results show that no Zn or Ag elements were identified in the control cells of all three strains tested with either NPs but both elements were found on all respectively treated cells (Figures 4 e, 5e, 6e, 7e, 8 e and 9e).

\subsection{Determination of Membrane Leakage}

For all three bacteria, the absorbance at $260 \mathrm{~nm}$ slightly increased after $10 \mathrm{~h}$ of exposure to $\mathrm{ZnO}$ NPs and $6 \mathrm{~h}$ of exposure to Ag NPs as compared to the controls, which may 
be attributed to leakage of nucleic acids from cells whose membranes were damaged. However, there were no significant differences $(p \leq 0.05)$ in absorbance between the control and treated samples, except for $B$. animalis treated with the highest concentration of $20 \mathrm{mM} \mathrm{ZnO}$ and L. acidophilus treated with the highest concentration of $4.6 \mathrm{nM} \mathrm{Ag} \mathrm{NPs}$ (Figure 10a,b). A similar trend was observed for protein leakage (Figure 10c,d) [30].

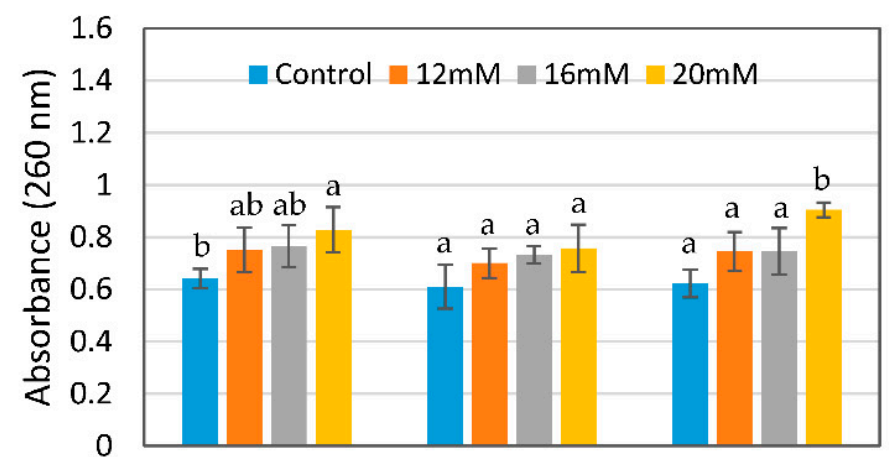

$\begin{array}{llll}\text { E. coli } & \text { L. acidophilus } & \text { B. animalis }\end{array}$

a

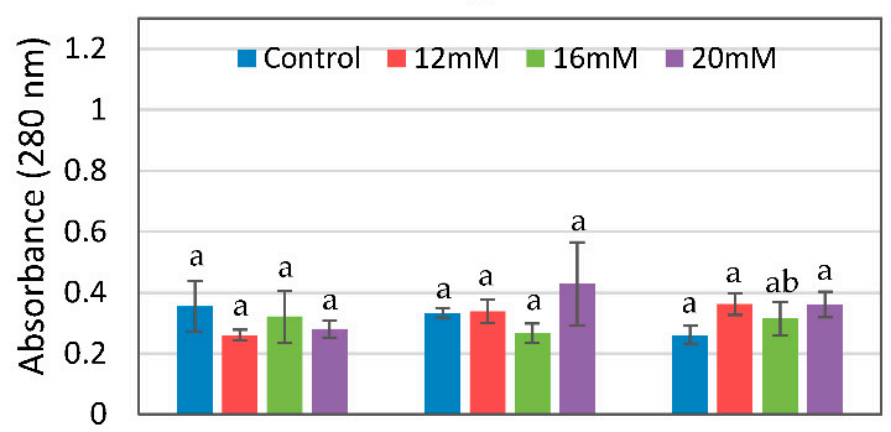

E. coli $\quad$ L. acidophilus $\quad$ B. animalis

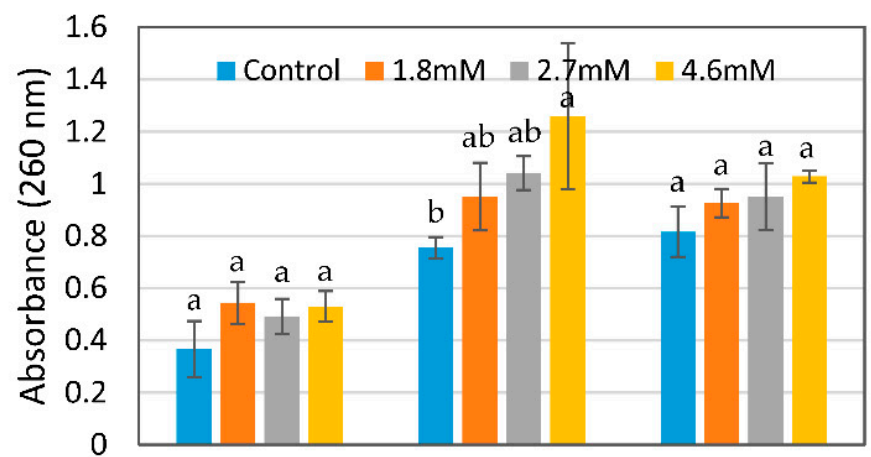

E. coli

L. acidophilus

B. animalis

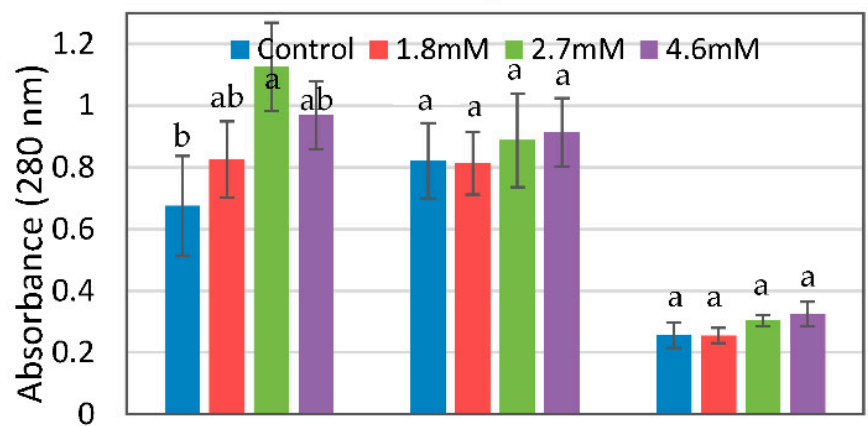

E. coli

L. acidophilus

B. animalis

c

d

Figure 10. Nucleic acid (a,b) and protein (c,d) leakage from E. coli, L. acidophilus, and B. animalis after treatment with ZnO NPs $(\mathbf{a}, \mathbf{c})$ for $10 \mathrm{~h}$ and Ag NPs $(\mathbf{b}, \mathbf{d})$ for $6 \mathrm{~h}$, as measured by absorbance at $260 \mathrm{~nm}$ and $280 \mathrm{~nm}$, respectively. Different lowercase letters $(a, b)$ indicate significant differences $(p \leq 0.05)$.

\subsection{Viability of Bacterial Cells}

Images of E. coli control and ZnO NP-treated samples demonstrate mostly green fluorescence which indicated the presence of live cells (Figure 11a,d). Very few red fluorescent cells, indicating dead cells, were seen in the treated sample (Figure 11d), which supports the growth study results (Figure 1a) that demonstrated no significant effects $(p \leq 0.05)$ of ZnO NPs on E. coli growth, and the SEM/TEM images as shown on Figure 4. L. acidophilus and B. animalis showed similar morphological changes as those observed in the SEM/TEM images (Figures 5 and 6) after treatment with ZnO NPs. Green fluorescent cells were observed in the control images with straight rod-shaped cells formed in a chain while, treated cells were formed in clusters or twisted around one another. However, not all twisted cells showed red fluorescence, which indicates that not all deformed cells were dead (Figures 9e and 11e). The results support the plate count numbers shown in Figure $2 \mathrm{~b}, \mathrm{c}$ ), that showed about $10^{8} \mathrm{CFU} / \mathrm{mL}$ of bacterial cells. This indicates that $20 \mathrm{mM}$ $\mathrm{ZnO}$ NPs did not result in leakage of internal contents and death of all L. acidiphilus and B. animalis cells. 

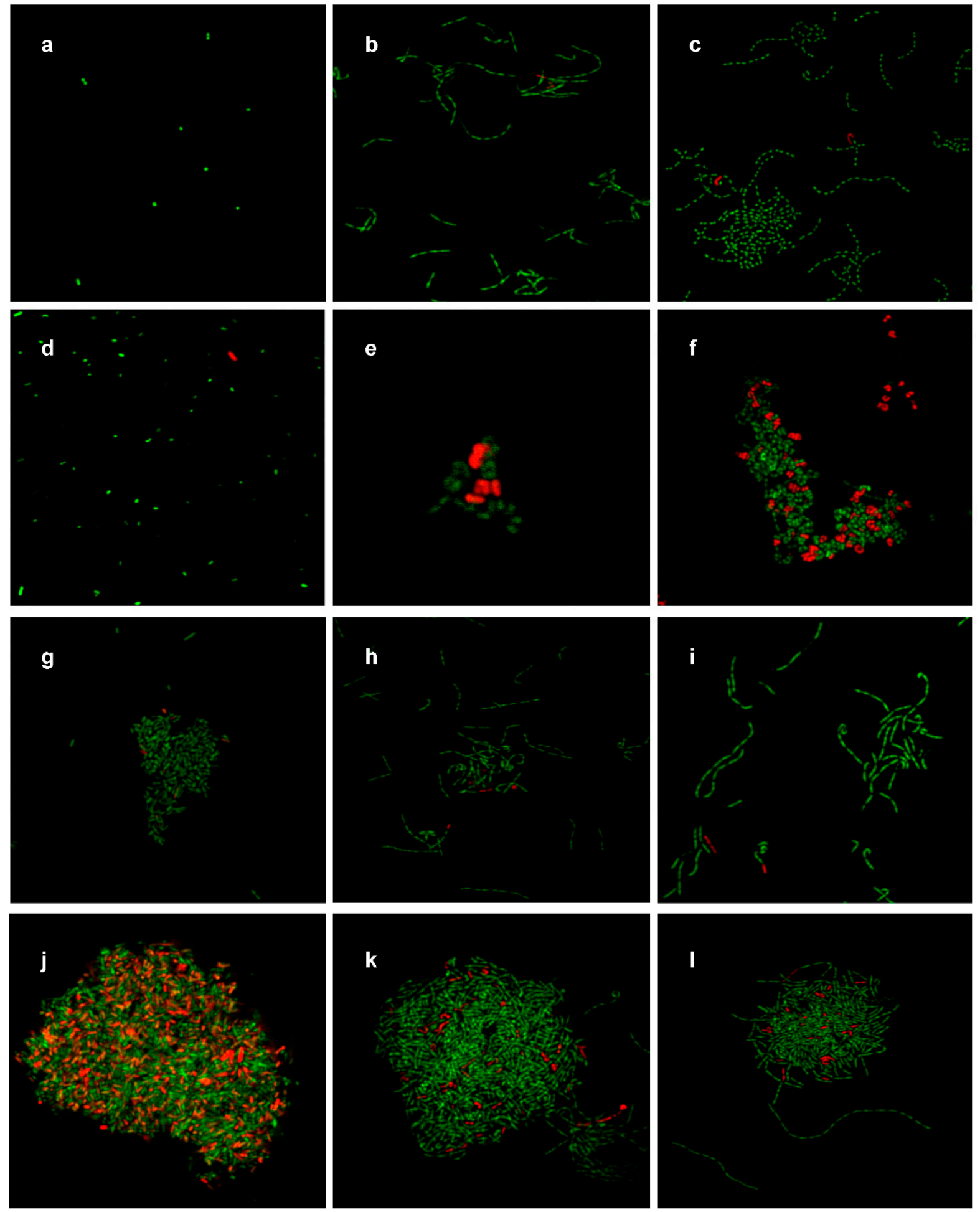

Figure 11. BacLight ${ }^{\mathrm{TM}}$ fluorescence microscopic images of untreated E. coli (a,g), L. acidophilus $(\mathbf{b}, \mathbf{h})$ and B. animalis (c,i);

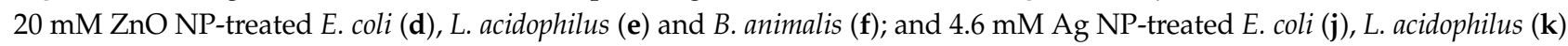
and B. animalis (1). Green indicates live cells while red indicates dead cells.

For cells treated with $4.6 \mathrm{mM} \mathrm{Ag} \mathrm{NPs,} \mathrm{many} \mathrm{red} \mathrm{fluorescent} \mathrm{cells,} \mathrm{indicating} \mathrm{dead}$ cells, were observed, especially for E. coli samples (Figure 11j) as compared to the untreated control (Figure 11g), which supported the results from the growth study (Figure 2a) and the SEM/TEM images (Figure 7). Overall, a higher number of dead E. coli cells were observed following Ag NP treatment as compared to ZnO NP treatment. Mostly green fluorescent 
cells with straight rod shapes were observed in the untreated sample of L.acidophilus and B. animalis (Figure 11h,i), and both green and red fluorescent cells, in large clusters, were observed in the treated samples (Figure 11k,l). However, as compared to the ZnO NP treatment, more green fluorescent cells than red were observed in the treated samples, which indicated that more live cells of L. acidophilus and B. animalis were present. Thus, the results of the viability of cells show that not all cells were equally affected by $\mathrm{ZnO}$ or $\mathrm{Ag}$ NPs and resulted in cell death [30].

\section{Discussion}

In this study, the effects of $\mathrm{ZnO}$ and Ag NPs on the intestinal bacteria, E. coli, L. acidophilus and $B$. animalis were investigated. Compared to the antimicrobial effects of these NPs on pathogenic microorganisms demonstrated in previous studies $[5,7,9,11,21-29,32-39]$, not much is known about the behavior of these NPs upon ingestion and whether they inhibit natural gut microflora. Antimicrobial properties of NPs have been shown to be dependent on their size and concentration, with increasing cytotoxicity at smaller sizes and higher concentrations $[9,10,12-15,23,24,40]$.

The results in Figure $2 b, c$ showed that the number of L. acidophilus and B. animalis treated with $\mathrm{ZnO}$ NPs was less than the control for up to 7-12 h of incubation, but subsequently followed similar patterns as the control and NP-free sample. This result is supported by a previous study that showed that, in addition to particle size and concentration of NPs, the antibacterial activity of NPs is also exposure time-dependent [24]. The results in Figure 2 indicated that concentrations of ZnO NPs higher than $12 \mathrm{mM}$ showed mild inhibitory effects on the growth of the two Gram-positive bacteria, L. acidophilus and B. animalis, and no inhibitory effects on the growth of the Gram-negative E. coli. Similar results were observed in a study by Baek and An (2011) [32] in which Staphylococcus aureus and Bacillus subtilis (Gram-positive) were more susceptible than E. coli (Gram-negative) to $\mathrm{NiO}$ and $\mathrm{ZnO}$ NPs. The biosorption of metal NPs to bacterial cells depends not only on the types of NPs, but also on the microbial species [41]. A possible mechanism of antimicrobial effects of $\mathrm{ZnO}$ NPs has been suggested in several studies $[8,9,42]$ as being generally triggered by the induction of oxidative stress by free radical formation that results in cell death. According to Pan et al. (2009) [43], ZnO NPs have weak mutagenic properties that induce frameshift mutations in Salmonella Typhimurium. However, there are many reports on the antibacterial effect of NPs that contradict one another which indicate that the inhibitory mechanisms of antimicrobial agents are very complicated and depend on many factors. Also, there are several bacteria that are present in the environment that naturally adapt to NPs and become tolerant to these compounds [44]. Hence, there is also a possibility that this might be the reason for our observations of the lack of inhibitory effects of $\mathrm{ZnO}$ NPs on E. coli in this study.

The results shown in Figure 3 indicate that Ag NPs had a significant inhibitory effect $(p \leq 0.05)$ on E. coli but less so on L. acidophilus and B. animalis. The mechanisms of the inhibitory effects of Ag NPs on microorganisms are partially known. Some studies have reported that the positive charge on the $\mathrm{Ag}^{+}$ion is crucial for its antimicrobial activity through electrostatic attractions between the negatively-charged cell membrane of microorganisms and positively-charged Ag NPs [33,34,37,45]. However, there is almost no $\mathrm{Ag}^{+}$ion release under anaerobic conditions, indicating that oxygen dissolved in water is necessary to convert $\mathrm{Ag} \mathrm{NPs}$ to $\mathrm{Ag}^{+}$ions $[38,46]$. Because they are both facultative anaerobes, L. acidophilus and B. animalis were incubated in anaerobic conditions. Hence, there was not enough oxygen available for the Ag NPs to release $\mathrm{Ag}^{+}$ions. This could explain why these two bacteria were less inhibited by Ag NPs as compared to E. coli. Without oxygen, Ag NPs cannot release $\mathrm{Ag}^{+}$ions which would have affected the growth of the bacterial cells. The slight inhibitory effect on the growth of L. acidophilus and B. animalis may be due to the exposure of the Ag NPs to oxygen during preparation and experiments that resulted in the release of minimal numbers of $\mathrm{Ag}^{+}$ions. Additionally, compared to Ag NPs, ZnO NPs showed higher inhibitory effects on L. acidophilus and B. animalis. This 
is because $\mathrm{ZnO}$ NPs can release $\mathrm{Zn}^{+}$ions regardless of the presence of oxygen. Another possible mechanism, as described by Amro et al. (2000) [47], is that metal depletion may cause the formation of irregularly-shaped pits on the outer membrane of cells that can change the membrane permeability and cause leakage of internal cell contents. However, the exact mechanisms of the antibacterial property of NPs to different types of bacteria are still not completely understood.

Unlike the results of ZnO NPs on E. coli, which showed higher antimicrobial effects than Ag NPs to L. acidophilus and B. animalis, other studies showed similar results as those observed in this study. E. coli O157:H7 cells were inhibited by Ag NPs at lower concentrations as compared to $S$. aureus [11]. Also, the minimum inhibitory concentration of Ag NPs was lower when testing against E. coli than when testing against $S$. aureus [24]. However, there is no supporting evidence to explain the species sensitivity to NPs.

As shown in Figures 4-9, compared to cells without NP treatment which showed well-organized single cells and non-clustered cells, cells treated with $\mathrm{ZnO}$ or Ag NPs agglomerated together and formed large clusters. A possible explanation may be electrostatic attractions between the negatively-charged cell membrane of the cells and the positivelycharged $\mathrm{Zn}^{+}$or $\mathrm{Ag}^{+}$ions from NPs. Further, although L. acidophilus and B. animalis were incubated in anaerobic conditions, similar agglomerations of both NPs were observed. This may be due to the exposure of Ag NPs to oxygen and the release of $\mathrm{Ag}^{+}$ions during preparation of the bacterial viability assay and fluorescence microscopy that subsequently reacted with the negatively-charged bacterial surfaces.

In summary, our results showed that bacterial strains exposed to ZnO NPs for $10 \mathrm{~h}$ and Ag NPs for $6 \mathrm{~h}$ assumed the most antimicrobial effect. However, the number of treated cells were within $1 \log \mathrm{CFU} / \mathrm{mL}$ less than that of the control and the reduction percentage in the number of cells was about $10 \%$ or less. The results of SEM and TEM images and EDS demonstrated the morphological changes of the cells and the adherence of the NPs to bacterial cells. Some externally and internally damaged cells were observed. However, not all cells were damaged, and there were still many cells in normal size with intact intracellular structures and well-organized intracellular contents which correlated with the results of cell reduction. Also, UV absorbance values indicated that no significant amounts of internal cellular contents were leaked due to NP exposures (Figure 10). Finally, the viability assay of bacterial cells confirmed that more live than dead cells were present after treatment with NPs. The overall results indicate that not all cells were affected by NPs (Figure 11).

\section{Conclusions}

In this study, the antimicrobial effects of $\mathrm{ZnO}$ and $\mathrm{Ag}$ NPs on three important intestinal bacteria were determined because of the potential exposure of intestinal flora to these nanoparticles. According to the results obtained in this study, it can be concluded that $\mathrm{ZnO}$ and Ag NPs have mild inhibitory effects on the three common intestinal bacteria tested. It should be noted that the contamination level of $\mathrm{ZnO}$ and Ag NPs in food samples, if present, would be very low, and much higher concentrations of NPs were tested in this study. The data obtained from this study indicate that food contaminated with $\mathrm{ZnO}$ and Ag NPs may offer only a negligible threat to the specific beneficial gut bacteria tested. However, mechanisms of antimicrobial effects of NPs are not yet fully understood. Studies in this area have reported various mechanisms of action of NPs, most widely reported being the generation of reactive oxygen species that subsequently lead to cellular disruptions [48,49]. Data from one study may not be comparable to those of others due to differences in sizes of NPs tested, manner in which they have been generated, and conditions of exposure of the NPs to the cells being tested. Continued studies on the mechanisms of antibacterial effects of $\mathrm{ZnO}$ and Ag NPs are clearly needed. In addition, there are limitations, such as stability, bioaccumulation, and toxicity features when synthesizing NPs using chemical vapor deposition, sol-gel process, spray pyrolysis, laser pyrolysis, and molecular condensation methods [50,51]. Recently, the green synthesis 
method offers a novel and potential alternative way to chemically-synthesized NPs [16-19]. For further studies, investigations into the antimicrobial effects of NPs synthesized by green synthesis methods on various kinds of bacteria would be worthwhile.

Author Contributions: Conceptualization, A.M. and M.L.; methodology, A.M.; validation A.M. and A.Y.; formal analysis, A.Y.; investigation, A.M., M.L., A.Y.; resources, A.M., M.L.; writing-original draft preparation, A.Y.; writing-review and editing, A.M. and M.L., supervision, A.M.; project administration, M.L. and A.M.; funding acquisition, M.L. and A.M. All authors have read and agreed to the published version of the manuscript.

Funding: This research was funded by the U.S. Department of Agriculture NIFA Nanotechnology Program (2011-67021-30391) and the University of Missouri Research Board.

Institutional Review Board Statement: Not applicable.

Informed Consent Statement: Not applicable.

Data Availability Statement: The data presented in this study are available by request to the corresponding author.

Acknowledgments: We acknowledge the assistance from the Electron Microscopy and Molecular Cytology Core facilities at the University of Missouri in microscopic analyses. This research was supported by the United States Department of Agriculture NIFA Nanotechnology Program (201167021-30391) and the University of Missouri Research Board.

Conflicts of Interest: The authors declare no conflict of interest.

\section{References}

1. Sekhon, B.S. Food nanotechnology-An overview. Nanotechnol. Sci. Appl. 2010, 3, 1-15. [PubMed]

2. Chakraborty, M.; Jain, S.; Rani, V. Nanotechnology: Emerging tool for diagnostics and therapeutics. Appl. Biochem. Biotechnol. 2011, 165, 1178-1187. [CrossRef]

3. Mahmoudi, M.; Hofmann, H.; Rothen-Rutishauser, B.; Petri-Fink, A. Assessing the in vitro and in vivo toxicity of superparamagnetic iron oxide nanoparticles. Chem. Rev. 2012, 112, 2323-2338. [CrossRef]

4. Mihindukulasuriya, S.D.F.; Lim, L.T. Nanotechnology development in food packaging: A review. Trends Food Sci. Technol. 2014, 40, 149-167. [CrossRef]

5. Duncan, T.V. Applications of nanotechnology in food packaging and food safety: Barrier materials, antimicrobials and sensors. J. Colloid Interface Sci. 2011, 363, 1-24. [CrossRef] [PubMed]

6. Maillard, J.-Y.; Hartemann, P. Silver as an antimicrobial: Facts and gaps in knowledge. Crit. Rev. Microbiol. 2013, 39, 373-383. [CrossRef] [PubMed]

7. Fu, G.; Vary, P.S.; Lin, C.T. Anatase $\mathrm{TiO}_{2}$ nanocomposites for antimicrobial coatings. J. Phys. Chem. B 2005, 109, 8889-8898. [CrossRef]

8. Sawai, J. Quantitative evaluation of antibacterial activities of metallic oxide powders $(\mathrm{ZnO}, \mathrm{MgO}$ and $\mathrm{CaO})$ by conductimetric assay. J. Microbiol. Methods 2003, 54, 177-182. [CrossRef]

9. Jones, N.; Ray, B.; Ranjit, K.T.; Manna, A.C. Antibacterial activity of ZnO nanoparticle suspensions on a broad spectrum of microorganisms. FEMS Microbiol. Lett. 2008, 279, 71-76. [CrossRef]

10. Palanikumar, L.; Ramasamy, S.N.; Balachandran, C. Size-dependent antimicrobial response of zinc oxide nanoparticles. IET Nanobiotechnol. 2014, 8, 111-117. [CrossRef]

11. Kim, J.S.; Kuk, E.; Yu, K.N.; Kim, J.-H.; Park, S.J.; Lee, H.J.; Kim, S.H.; Park, Y.K.; Park, Y.H.; Hwang, C.-Y. Antimicrobial effects of silver nanoparticles. Nanomed. Nanotechnol. Biol. Med. 2007, 3, 95-101. [CrossRef]

12. Gliga, A.R.; Skoglund, S.; Odnevall Wallinder, I.; Fadeel, B.; Karlsson, H.L. Size-dependent cytotoxicity of silver nanoparticles in human lung cells: The role of cellular uptake, agglomeration and Ag release. Part. Fibre Toxicol. 2014, 11, 1-17. [CrossRef]

13. Jeong, Y.; Lim, D.W.; Choi, J. Assessment of size-dependent antimicrobial and cytotoxic properties of silver nanoparticles. Adv. Mater. Sci. Eng. 2014, 2014, 1-6. [CrossRef]

14. Wahab, R.; Kim, Y.-S.; Mishra, A.; Yun, S.-I.; Shin, H.-S. Formation of ZnO micro-flowers prepared via solution process and their antibacterial activity. Nanoscale Res. Lett. 2010, 5, 1675-1681. [CrossRef]

15. Yin, H.; Casey, P.S.; McCall, M.J.; Fenech, M. Effects of surface chemistry on cytotoxicity, genotoxicity, and the generation of reactive oxygen species induced by ZnO nanoparticles. Langmuir 2010, 26, 15399-15408.

16. Singh, J.; Dutta, T.; Kim, K.H.; Rawat, M.; Samddar, P.; Kumar, P. 'Green' synthesis of metals and their oxide nanoparticles: Applications for environmental remediation. J. Nanobiotechnol. 2018, 16, 1-24. [CrossRef]

17. Ullah, N.; Yasin, S.; Abro, S.; Liu, L.; Wei, Q. Mechanically robust and antimicrobial cotton fibers loaded with silver nanoparticles: Synthesized via Chinese Holly plant leaves. Int. J. Text. Sci. 2014, 3, 1-5. 
18. Ullah, N.; Li, D.; Xiaodong, C.; Yasin, S.; Muhammed Umair, M.; Shan Van Eede, S.; Wei, Q. Photo-irradiation based biosynthesis of silver nanoparticles by using an evergreen shrub and its antibacterial study. Dig. J. Nanomater. Biostruct. 2015, 10, 95-105.

19. Alsammarraie, F.K.; Wang, W.; Zhou, P.; Mustapha, A.; Lin, M. Green synthesis of silver nanoparticles using turmeric extracts and investigation of their antibacterial activities. Colloids Surf. B Biointerfaces 2018, 171, 398-405. [CrossRef]

20. Akbar, A.; Sadiq, M.B.; Ali, I.; Muhammad, N.; Rehman, Z.; Khan, M.N.; Muhammad, J.; Khan, S.A.; Rehman, F.U.; Anal, A.K. Synthesis and antimicrobial activity of zinc oxide nanoparticles against foodborne pathogens Salmonella typhimurium and Staphylococcus aureus. Biocatal. Agric. Biotechnol. 2019, 17, 36-42. [CrossRef]

21. Brayner, R.; Ferrari-Iliou, R.; Brivois, N.; Djediat, S.; Benedetti, M.F.; Fiévet, F. Toxicological impact studies based on Escherichia coli bacteria in ultrafine $\mathrm{ZnO}$ nanoparticles colloidal medium. Nano Lett. 2006, 6, 866-870. [CrossRef] [PubMed]

22. Jin, T.; Sun, D.; Su, J.; Zhang, H.; Sue, H.J. Antimicrobial efficacy of zinc oxide quantum dots against Listeria monocytogenes, Salmonella Enteritidis, and Escherichia coli O157: H7. J. Food Sci. 2009, 74, M46-M52. [CrossRef] [PubMed]

23. Liu, Y.; He, L.; Mustapha, A.; Li, H.; Hu, Z.; Lin, M. Antibacterial activities of zinc oxide nanoparticles against Escherichia coli O157: H7. J. Appl. Microbiol. 2009, 107, 1193-1201. [CrossRef] [PubMed]

24. Martinez-Castanon, G.; Nino-Martinez, N.; Martinez-Gutierrez, F.; Martinez-Mendoza, J.; Ruiz, F. Synthesis and antibacterial activity of silver nanoparticles with different sizes. J. Nanoparticle Res. 2008, 10, 1343-1348. [CrossRef]

25. Mirhosseini, M.; Firouzabadi, F.B. Antibacterial activity of zinc oxide nanoparticle suspensions on food-borne pathogens. Int. J. Dairy Technol. 2013, 66, 291-295. [CrossRef]

26. Raffi, M.; Hussain, F.; Bhatti, T.; Akhter, J.; Hameed, A.; Hasan, M. Antibacterial characterization of silver nanoparticles against E. coli ATCC-15224. J. Mater. Sci. Technol. 2008, 24, 192-196.

27. Sondi, I.; Salopek-Sondi, B. Silver nanoparticles as antimicrobial agent: A case study on E. coli as a model for Gram-negative bacteria. J. Colloid Interface Sci. 2004, 275, 177-182. [CrossRef]

28. Tayel, A.A.; EL-TRASW, F.; Moussa, S.; EL-BAZA, F.; Mahrous, H.; Salem, M.F.; Brimer, L. Antibacterial action of zinc oxide nanoparticles against foodborne pathogens. J. Food Saf. 2011, 31, 211-218. [CrossRef]

29. Xie, Y.; He, Y.; Irwin, P.L.; Jin, T.; Shi, X. Antibacterial activity and mechanism of action of zinc oxide nanoparticles against Campylobacter jejuni. Appl. Environ. Microbiol. 2011, 77, 2325-2331. [CrossRef]

30. Yoo, A. Effect of Zinc Oxide and Silver Nanoparticles on Intestinal Bacteria. Master's Thesis, University of Missouri, Columbia, MO, USA, 2013.

31. Nain, R.; Chauhan, R.P. Colloidal synthesis of silver nano particles. Asian J. Chem. 2009, 21, 113-116.

32. Baek, Y.-W.; An, Y.-J. Microbial toxicity of metal oxide nanoparticles $\left(\mathrm{CuO}, \mathrm{NiO}, \mathrm{ZnO}\right.$, and $\left.\mathrm{Sb}_{2} \mathrm{O}_{3}\right)$ to Escherichia coli, Bacillus subtilis, and Streptococcus aureus. Sci. Total Environ. 2011, 409, 1603-1608. [CrossRef]

33. Choi, O.; Hu, Z. Size dependent and reactive oxygen species related nanosilver toxicity to nitrifying bacteria. Environ. Sci. Technol. 2008, 42, 4583-4588. [CrossRef] [PubMed]

34. Dibrov, P.; Dzioba, J.; Gosink, K.K.; Häse, C.C. Chemiosmotic mechanism of antimicrobial activity of Ag+ in Vibrio cholera. Antimicrob. Agents Chemother. 2002, 46, 2668-2670. [CrossRef]

35. Ghule, K.; Ghule, A.V.; Chen, B.J.; Ling, Y.C. Preparation and characterization of ZnO nanoparticles coated paper and its antibacterial activity study. Green Chem. 2006, 8, 1034-1041. [CrossRef]

36. Hajipour, M.J.; Fromm, K.M.; Ashkarran, A.A.; de Aberasturi, D.J.; de Larramendi, I.R.; Rojo, T.; Serpooshan, V.; Parak, W.J.; Mahmoudi, M. Antibacterial properties of nanoparticles. Trends Biotechnol. 2012, 30, 499-511. [CrossRef]

37. Hamouda, T.; Myc, A.; Donovan, B.; Shih, A.Y.; Reuter, J.D.; Baker, J.R. A novel surfactant nanoemulsion with a unique non-irritant topical antimicrobial activity against bacteria, enveloped viruses and fungi. Microbiol. Res. 2001, 156, 1-7. [CrossRef] [PubMed]

38. Liu, H.-L.; Dai, S.A.; Fu, K.-Y.; Hsu, S.-H. Antibacterial properties of silver nanoparticles in three different sizes and their nanocomposites with a new waterborne polyurethane. Int. J. Nanomed. 2010, 5, 1017.

39. Zhang, L.; Jiang, Y.; Ding, Y.; Povey, M.; York, D. Investigation into the antibacterial behaviour of suspensions of ZnO nanoparticles (ZnO nanofluids). J. Nanoparticle Res. 2007, 9, 479-489. [CrossRef]

40. Feris, K.; Otto, C.; Tinker, J.; Wingett, D.; Punnoose, A.; Thurber, A.; Kongara, M.; Sabetian, M.; Quinn, B.; Hanna, C.; et al. Electrostatic interactions affect nanoparticle-mediated toxicity to gram-negative bacterium Pseudomonas aeruginosa PAO1. Langmuir 2010, 26, 4429-4436. [CrossRef]

41. Hassan, A.A.; Sandre, O.; Cabuil, V.; Tabeling, P. Synthesis of iron oxide nanoparticles in a microfluidic device: Preliminary results in a coaxial flow millichannel. Chem. Commun. 2008, 1783-1785. [CrossRef] [PubMed]

42. Li, X.; Wang, L.; Fan, Y.; Feng, Q.; Cui, F.Z. Biocompatibility and toxicity of nanoparticles and nanotubes. J. Nanomater. 2012, 2012, 6. [CrossRef]

43. Pan, Z.; Lee, W.; Slutsky, L.; Clark, R.A.; Pernodet, N.; Rafailovich, M.H. Adverse effects of titanium dioxide nanoparticles on human dermal fibroblasts and how to protect cells. Small 2009, 5, 511-520. [CrossRef]

44. Wu, B.; Huang, R.; Sahu, M.; Feng, X.; Biswas, P.; Tang, Y.J. Bacterial responses to Cu-doped $\mathrm{TiO}_{2}$ nanoparticles. Sci. Total Environ. 2010, 408, 1755-1758. [CrossRef] [PubMed]

45. Dragieva, I.; Stoeva, S.; Stoimenov, P.; Pavlikianov, E.; Klabunde, K. Complex formation in solutions for chemical synthesis of nanoscaled particles prepared by borohydride reduction process. Nanostructured Mater. 1999, 12, 267-270. [CrossRef]

46. Liu, J.; Hurt, R.H. Ion release kinetics and particle persistence in aqueous nano-silver colloids. Environ. Sci. Technol. 2010, 44, 2169-2175. [CrossRef] 
47. Amro, N.A.; Kotra, L.P.; Wadu-Mesthrige, K.; Bulychev, A.; Mobashery, S.; Liu, G.-Y. High-resolution atomic force microscopy studies of the Escherichia coli outer membrane: Structural basis for permeability. Langmuir 2000, 16, 2789-2796. [CrossRef]

48. McDonnell, G.; Russell, A.D. Antiseptics and disinfectants: Activity, action, and resistance. Clin. Microbiol. Rev. 1999, 12, 147-179. [CrossRef]

49. Pan, Y.; Neuss, S.; Leifert, A.; Fischler, M.; Wen, F.; Simon, U.; Schmid, G.; Brandau, W.; Jahnen-Dechent, W. Size-dependent cytotoxicity of gold nanoparticles. Small 2007, 3, 1941-1949. [CrossRef]

50. Dhand, C.; Dwivedi, N.; Loh, X.J.; Ying, A.N.; Verma, N.K.; Beuerman, R.W.; Lakshminarayanan, R.; Ramakrishna, S. Methods and strategies for the synthesis of diverse nanoparticles and their applications: A comprehensive overview. Res. Adv. 2015, 5, 105003-105037. [CrossRef]

51. Rane, A.V.; Kanny, K.; Abitha, V.K.; Thomas, S. Methods for synthesis of nanoparticles and fabrication of nanocomposites. In Synthesis of Inorganic Nanomaterials; Woodhead Publishing: Cambridge, UK, 2018; pp. 121-139. 